\title{
Opportunities for Energy, Water, and Waste Reduction at U.S. Forest Service Fire Camps
}

\author{
Alicen Kandt, Emma Elgqvist, \\ and Jimmy Salasovich
}

Produced under the direction of the U.S. Forest Service by the National Renewable Energy Laboratory (NREL) under Interagency Task No. WFED10386.

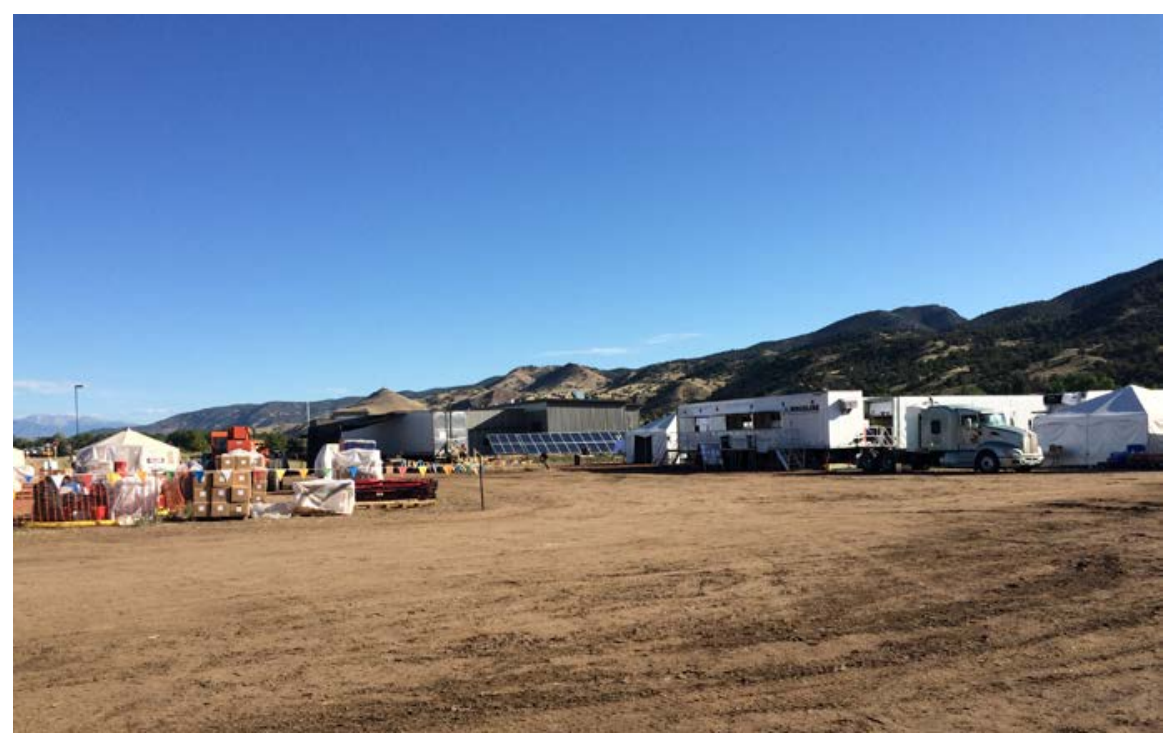

NREL is a national laboratory of the U.S. Department of Energy Office of Energy Efficiency \& Renewable Energy Operated by the Alliance for Sustainable Energy, LLC

This report is available at no cost from the National Renewable Energy Laboratory (NREL) at www.nrel.gov/publications.

Strategic Partnership Project Report NREL/TP-7A40-73771

April 2019

Contract No. DE-AC36-08GO28308 


\title{
GNREL
}

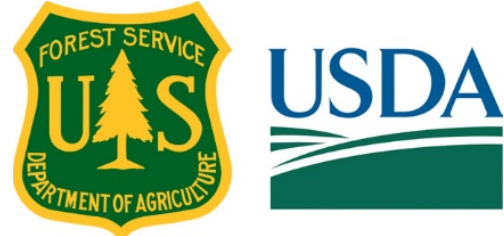

\section{Opportunities for Energy, Water, and Waste Reduction at U.S. Forest Service Fire Camps}

\author{
Alicen Kandt, Emma Elgqvist, \\ and Jimmy Salasovich
}

\section{Suggested Citation}

Kandt, Alicen, Emma Elgqvist, and Jimmy Salasovich. 2019. Opportunities for Energy, Water, and Waste Reduction at U.S. Forest Service Fire Camps. Golden, CO: National Renewable Energy Laboratory. NREL/ TP-7A40-73771. https://www.nrel.gov/docs/fy19osti/73771.pdf.

NREL is a national laboratory of the U.S. Department of Energy Office of Energy Efficiency \& Renewable Energy Operated by the Alliance for Sustainable Energy, LLC

This report is available at no cost from the National Renewable Energy Laboratory (NREL) at www.nrel.gov/publications.

National Renewable Energy Laboratory 15013 Denver West Parkway Golden, CO 80401 303-275-3000 • www.nrel.gov

\section{Strategic Partnership Project Report}

NREL/TP-7A40-73771

April 2019

Contract No. DE-AC36-08GO28308 


\section{NOTICE}

This work was authored by the National Renewable Energy Laboratory, operated by Alliance for Sustainable Energy, LLC, for the U.S. Department of Energy (DOE) under Contract No. DE-AC36-08GO28308. Funding provided by the U.S. Forest Service under Interagency Agreement IAG-15-1973. The views expressed herein do not necessarily represent the views of the DOE or the U.S. Government.

This report is available at no cost from the National Renewable Energy Laboratory (NREL) at www.nrel.gov/publications.

U.S. Department of Energy (DOE) reports produced after 1991 and a growing number of pre-1991 documents are available free via www.OSTI.gov.

NREL prints on paper that contains recycled content. 


\section{Preface}

As part of ongoing efforts by the U.S. Forest Service (USFS) to reduce energy use and incorporate sustainable and efficient practices into its operations, the USFS funded U.S. Department of Energy's National Renewable Energy Laboratory to conduct site visits and analyses of fire camp operations at six fires across the United States. This report documents the findings of those visits and provides suggestions for the implementation of energy, water, and waste conservation measures, and renewable energy measures. 


\section{Contacts}

\section{U.S. Forest Service}

Dennis Fiore

Cooperative Fire Program Manager/

Fire Prevention Coordinator

Phone: 505-808-2063

Email: djfiore@fs.fed.us

David Wiley

Capital Assets Program Manager

Phone: 703-605-4512

Email: davidrwiley@,fs.fed.us

Lara Y. Buluc

Sustainable Operations \&

Co-Climate Change Coordinator

Phone: 707-562-8937

Email: 1ara.buluc@usda.gov

\section{National Renewable Energy Laboratory}

\author{
Alicen Kandt \\ Project Leader, Senior Engineer \\ Phone: 303-384-7518 \\ Email: alicen.kandt@,nrel.gov \\ Emma Elgqvist \\ Engineer \\ Phone: 303-275-3606 \\ Emma.Elgqvist@nrel.gov \\ Jimmy Salasovich \\ Senior Engineer \\ Phone: 303-384-7383 \\ Email: james.salasovich@nrel.gov
}




\section{List of Acronyms}

CFL

DOE

EE

EUI

FAM

FY

GFT

ICP

IMT

NREL

RE

USFS

WE

WTE compact fluorescent lighting

Department of Energy

energy efficiency

energy-use intensity

Fire and Aviation Management

Fiscal Year

Greening Fire Team

Incident Command Post

Incident Management Team

National Renewable Energy Laboratory

renewable energy

U.S. Forest Service

water efficiency

waste to energy 


\section{Executive Summary}

This report summarizes the results from energy efficiency, water efficiency, waste reduction, and renewable energy site assessments conducted at fire camps located in the United States. A team led by the U.S. Department of Energy's National Renewable Energy Laboratory (NREL) conducted the assessments with U.S. Forest Service (USFS) personnel during the summers of 2016 and 2017 as part of ongoing efforts by the USFS to reduce energy use, water use, and waste generation, and to implement renewable energy technologies.

The Greening Fire Team (GFT) within the USFS was created in 2010 with the vision to achieve "net zero waste, water, and energy at all large fire incidents by 2030," and the mission to "integrate sustainability best management practices into the fire community." In 2015, staff from NREL began work with USFS staff to identify ways to improve the efficiency of fire camp operations, including decreasing energy use, water use, and generated waste. This effort began with an exercise to understand fire operations and associated energy and water use, as well as waste generation. NREL staff participated in monthly calls with GFT members, researched related efforts in similar operations, and conducted a data call to gather relevant energy, water, waste, and other operational data. NREL staff had difficulties procuring data on operational energy or water use and cost, or waste generation associated with fire camp operations.

In 2016, NREL staff along with USFS staff determined that visiting wildfire incidents would be the best way to understand the complicated logistical operations at fire camps and to begin to gather data, while attempting to identify operational efficiencies that could be implemented to reduce energy and water use, and waste generation. NREL staff and GFT members visited six fires: the Cold Springs and Hayden Pass fires (Colorado, 2016), and the Highline, Boundary, Milli, and Whitewater fires (Arizona and Oregon, 2017). At each fire, they visited the Incident Command Post, base camps, and a spike camp. The intent of the visits was to understand fire operations that relate to, are dependent on, or impact energy use, water use, and waste generation.

NREL staff gained invaluable insights during the visits to the fires and continued dialogue with Incident Management Team (IMT) staff supporting fire operations, but the lack of data made it difficult to quantify savings opportunities. Most opportunities for reduction cannot be economically quantified at this time; one of the team's priority recommendations was to create a central repository of data on costs incurred for energy and water procurement and waste removal in fire operations. These data would be useful to help justify the importance of sustainable measures and to quantify the value of such efforts. Another high-priority recommendation was to deploy an on-site sustainability coordinator for every fire.

The suggested best practices, including many observed during the visits to the fires, are listed below:

- Championing of sustainability: In general, most USFS staff and IMTs were highly motivated to incorporate sustainable measures into incident operations. Site champions will be influential in moving sustainable initiatives forward in the future, and it was very encouraging to encounter so many supportive staff and crews while visiting the fires. 
People generally embraced sustainability and conservation; they were observed turning off lights and air-conditioning when leaving tents, for instance.

- Composting: Current practices and contracting requirements ensure that catering contractors provide compostable utensils, plates, and cups, and collect these items and food waste in compostable bags. This is an effective first step in implementing composting in fire camp operations.

- Recycling: Some fire camps had comprehensive recycling options, including cardboard, plastics, glass, and even batteries. One camp contracted out these services to a vendor, resulting in a large increase in recycled materials and minimizing the burden to USFS staff associated with coordinating recycling efforts.

- Canteens: The use of canteens, or cubies, was broadly encouraged and often adopted. Potable water taps are provided on all fires, and the use of cubies helps reduce the plastic waste generated from plastic bottle use.

- Electrolyte powder: Some fire camps were piloting the use of electrolyte powder, which can be added to water in cubies, thus further reducing plastic waste generated from electrolyte (sports) drink plastic bottle use.

- Greening Fire Team efforts: The GFT worked to communicate opportunities to the fire community to make fire operations more sustainable, including the promotion of "Greening Fire Tips" (Appendix B) and the distribution of GFT stickers.

- Solar-powered radio repeater: One fire camp deployed a solar-powered radio repeater and indicated it was very effective. Adding a lead-acid battery further extended the operating hours, and the system was built to withstand harsh elements found in the field.

- Rechargeable battery radios: The use of radios with rechargeable lithium-ion battery has the potential to drastically reduce battery waste. This technology is already being effectively deployed in Alaska.

- LED lights: LED lights were observed in some fire camps, including light towers and tent lighting. LEDs are much more efficient than the incumbent incandescent lighting.

- Reuse and recycling at caches: Personnel at the various fires indicated that many of the tools and equipment taken from the main cache and used to fight a fire are reconditioned and reused for future fires. Recycling also occurs at the main cache.

NREL staff also identified a variety of reduction opportunities for energy, water, and waste. Potential best management practices include using renewable energy systems, specifying LED lights, offering more than one meal size, recycling and composting at every incident, and others. Each potential best management suggestion is described in detail, and potential next steps and considerations are provided. 


\section{Table of Contents}

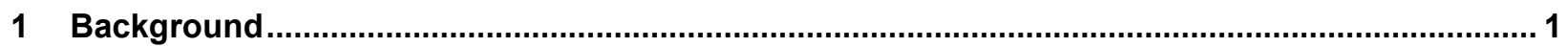

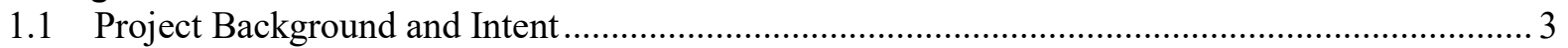

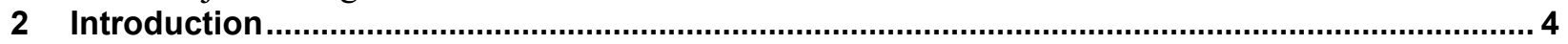

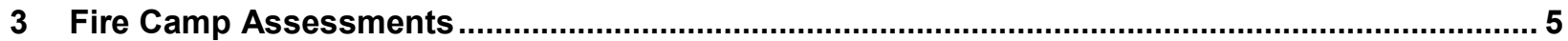

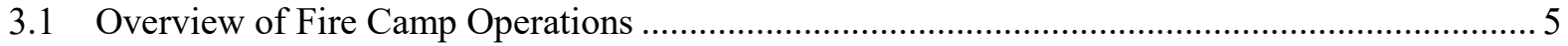

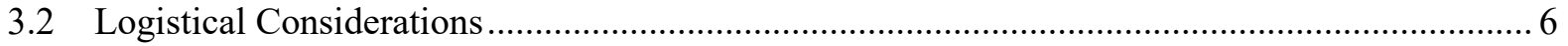

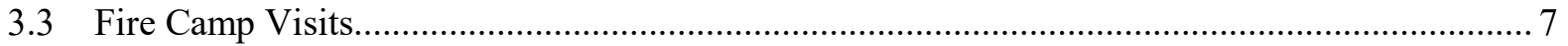

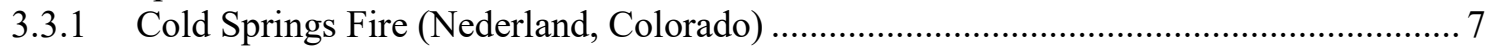

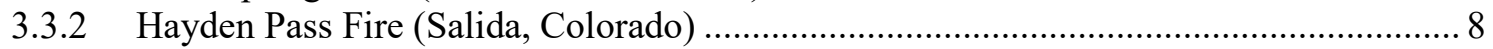

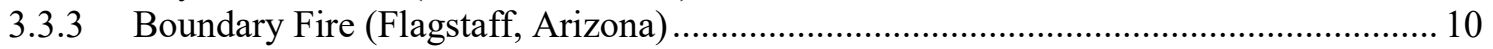

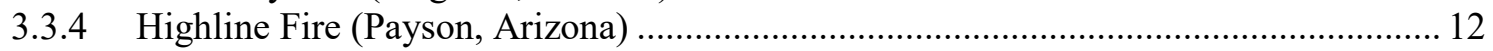

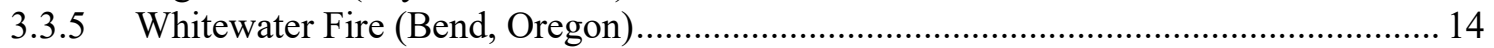

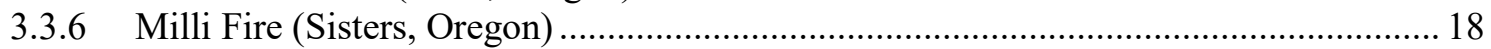

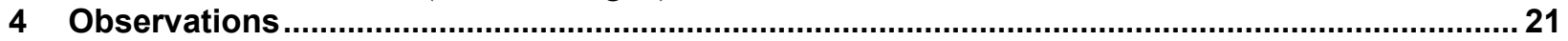

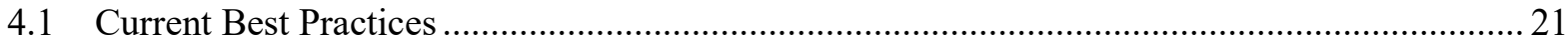

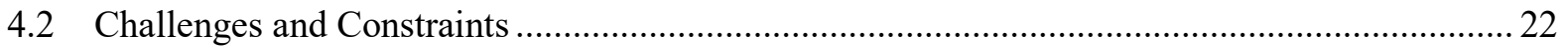

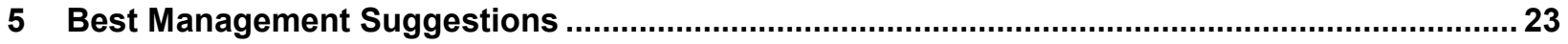

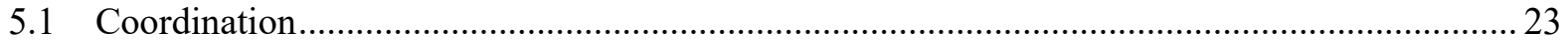

5.1.1 Sustainable Operations Coordinator for Every Incident ............................................ 23

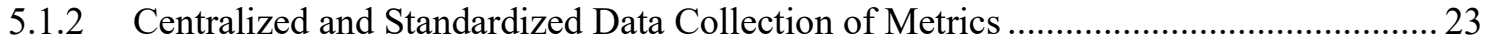

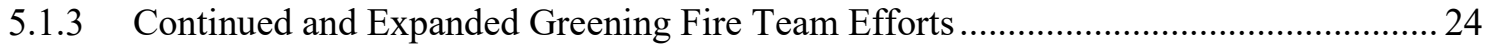

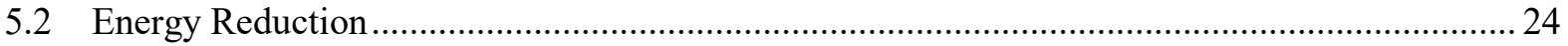

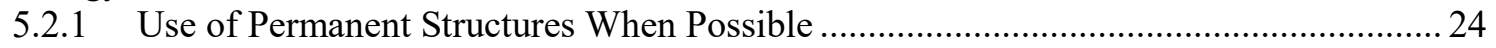

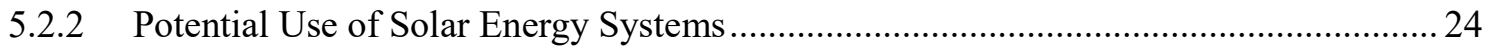

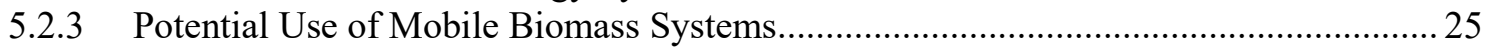

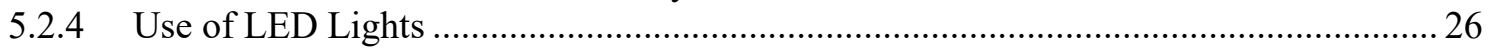

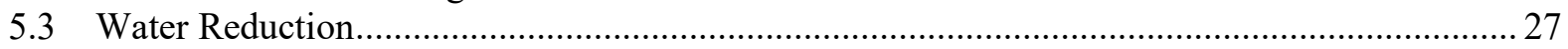

5.3.1 Vehicle Washing and Dust Abatement ............................................................. 27

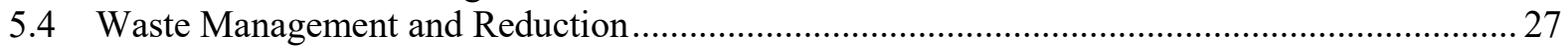

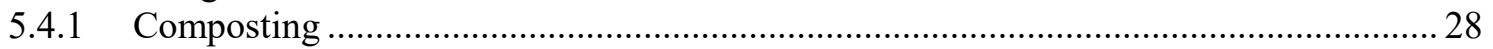

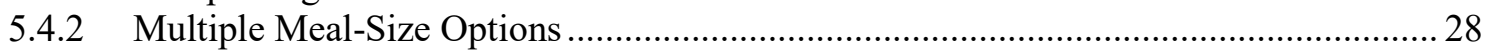

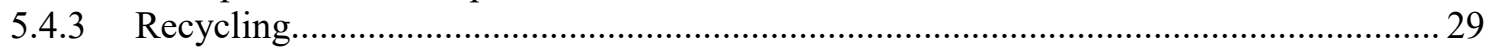

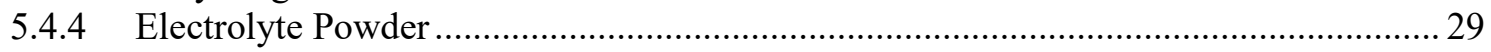

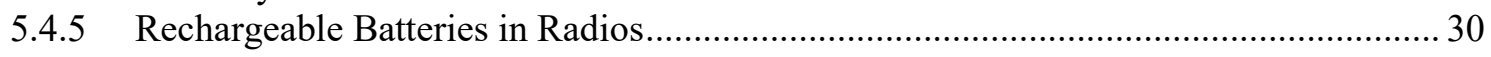

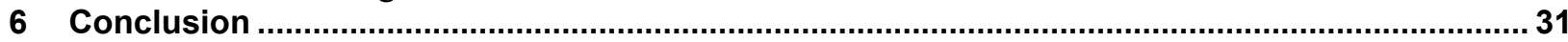

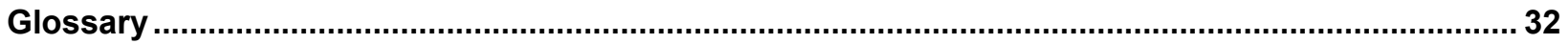

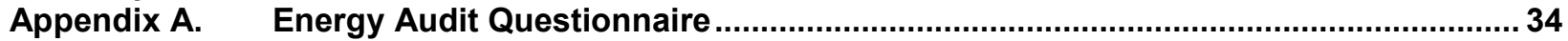

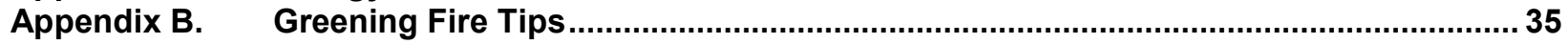

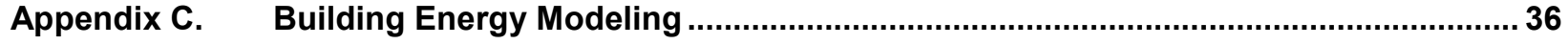

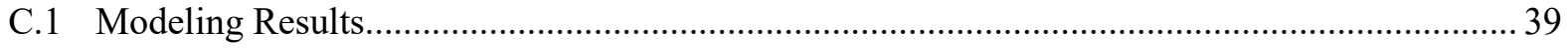




\section{List of Figures}

Figure 1. Percent of USFS annual appropriated budget allocated to firefighting ..................................... 1

Figure 2. Base camp at the Hayden Pass Fire near Salida, Colorado ................................................... 9

Figure 3. Handwashing and shower facilities at the Hayden Pass Fire .................................................... 9

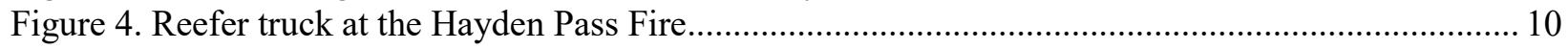

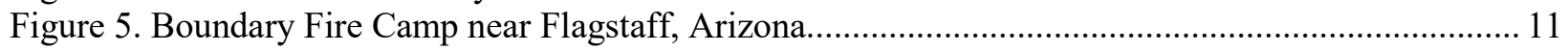

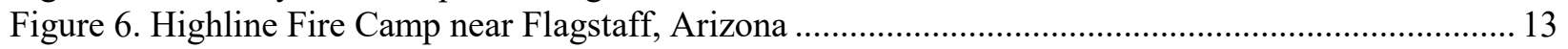

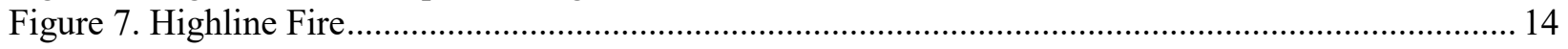

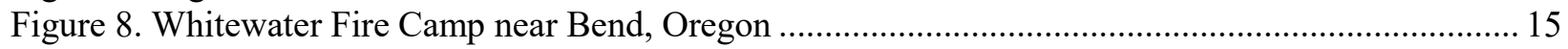

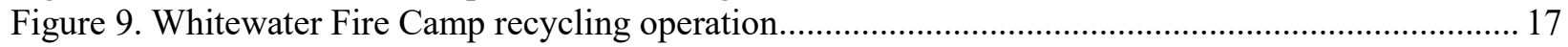

Figure 10. Whitewater Fire Camp solar-powered radio repeater........................................................... 18

Figure 11. Milli Fire Camp Near Sisters, Oregon........................................................................... 19

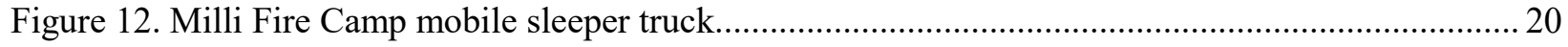

Figure 13. Dust abatement activities at the Hayden Pass Fire .............................................................. 27

Figure 14. Water and sport drink bottles for crews at the Cold Springs Fire base camp ..........................29

Figure 15. Representative tent photo and eQUEST model representation ............................................ 36

Figure 16. Representative mobile office trailer photo and eQUEST model representation........................ 37

Figure 17. Representative hard structure photo and eQUEST model representation ............................... 37

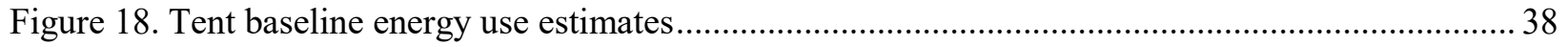

Figure 19. Mobile office trailer baseline energy use estimates............................................................. 38

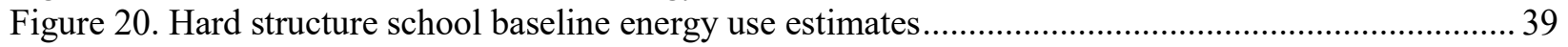

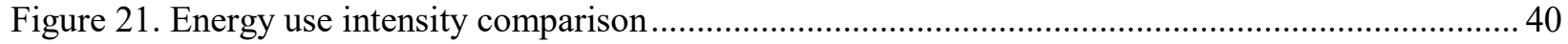

\section{List of Tables}

Table 1. Percent Reduction in Funding of USFS Programs...................................................................... 2

Table 2. Hayden Pass Fire Equipment Energy/Water Use ................................................................... 10 


\section{Background}

Over the past two decades, the U.S. Forest Service (USFS) budget dedicated to fighting fires has more than tripled - from 16\% of the USFS's annual appropriated budget in 1995 to more than $50 \%$ in 2015, as seen in Figure 1. In 2014, the USFS's 10 largest fires cost more than $\$ 320$ million. The annual cost of fire suppression is predicted to increase to nearly $\$ 1.8$ billion by 2025 .

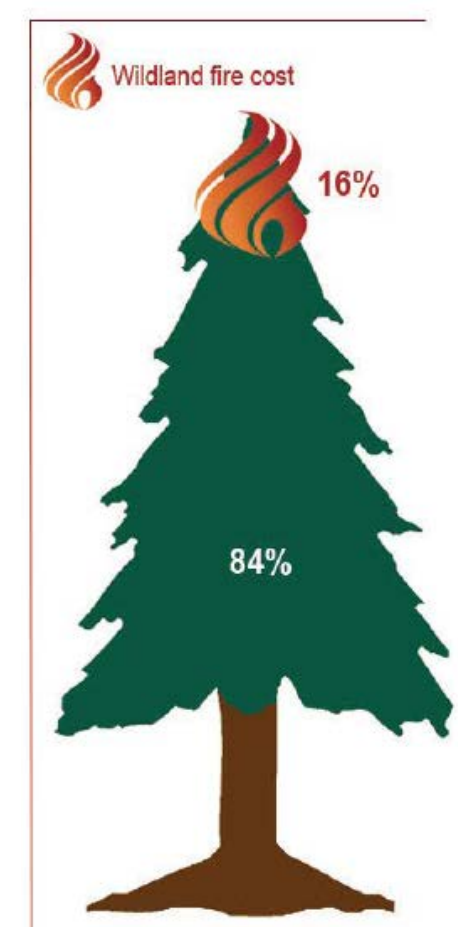

FY 1995
Yesterday, Today, and Tomorrow
Wildland Fire Cost Consumes

Forest Service Budget

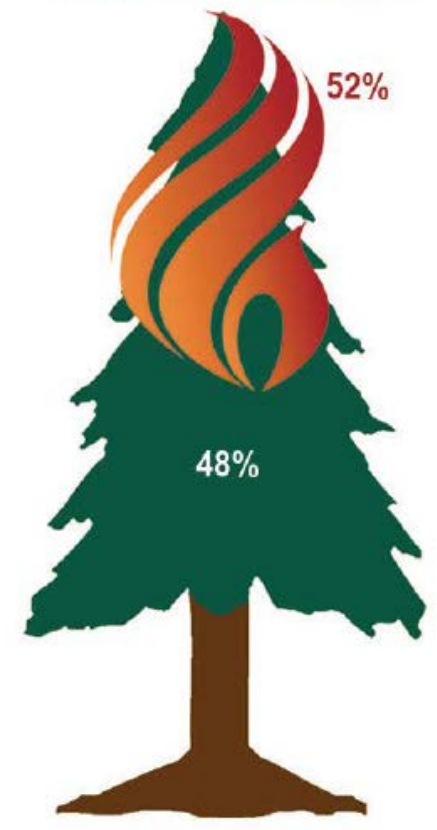

FY 2015

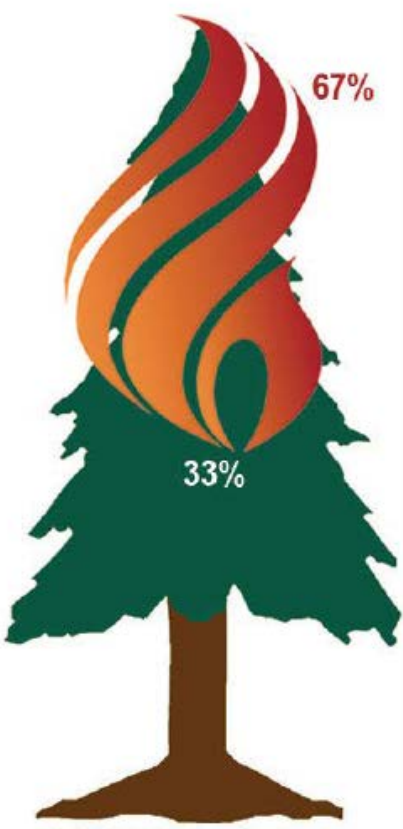

FY 2025 Projected

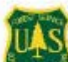

Figure 1. Percent of USFS annual appropriated budget allocated to firefighting ${ }^{1}$

As more of the agency's resources are spent each year to support firefighting efforts, fewer funds are available to support other agency work, including programs and restoration projects that reduce the fire threat. As seen in Table 1, USFS programs faced reductions in funding from Fiscal Year (FY) 2001 through FY 2015 ranging from 15\% to 95\%. ${ }^{2}$

In response to the record-setting fire suppression costs in 2017, Congress was able to find a bipartisan fix for the USFS's "fire borrowing" challenge. In the FY 2018 Consolidated Appropriations Act, Congress included a solution - new budget authority that will allow the USFS to use funding from a different budget source to avoid having to take funds from nonfire programs to cover the cost of fire suppression.

\footnotetext{
${ }^{1}$ The Rising Cost of Wildfire Operations: Effects on the Forest Service's Non-Fire Work (Washington, DC: U.S. Department of Agriculture-U.S. Forest Service, 2015).

${ }^{2}$ Ibid.
} 
Table 1. Percent Reduction in Funding of USFS Programs ${ }^{3}$

\begin{tabular}{|l|c|}
\hline \multicolumn{1}{|c|}{ USFS Program } & $\begin{array}{c}\text { Percent Reduction in Funding (\%) } \\
\text { (FY 2001-FY 2015) }\end{array}$ \\
\hline Deferred Maintenance & 95 \\
\hline Facilities & 68 \\
\hline Land Management Planning & 64 \\
\hline Roads & 46 \\
\hline Inventory and Monitoring & 35 \\
\hline Landownership Management & 33 \\
\hline $\begin{array}{l}\text { Vegetation and Watershed } \\
\text { Management }\end{array}$ & 24 \\
\hline $\begin{array}{l}\text { Wildlife and Fisheries Habitat } \\
\text { Management }\end{array}$ & 18 \\
\hline $\begin{array}{l}\text { Recreation, Heritage, and } \\
\text { Wilderness }\end{array}$ & 15 \\
\hline
\end{tabular}

In 2008, in response to Executive Order 13514 (Federal Leadership in Environmental, Energy, and Economic Performance), ${ }^{4}$ the Forest Service developed a strategic framework to address climate change. Of the seven goals created, Goal 5, Sustainable Operations (SusOps), targets the reduction of the environmental footprint of Forest Service operations and promotes being a leading example of a green organization. Tom Harbor, the Director of Fire and Aviation Management (FAM) at that time, reinforced this national goal in a 2009 letter, establishing the expectation that fire and aviation program managers set an example by: identifying and implementing actions to reduce the environmental footprint of operations with a focus on national interagency support caches, green purchasing, incident bases and camps, contracting, facilities and water conservation, transportation and fleet, and appropriate response to fire.

The national Greening Fire Team (GFT) came to fruition in 2010 with the intention to provide SusOps guidance to Incident Management Teams (IMTs) and to research, recommend, and assist with implementing sustainability efforts related to waste reduction, renewable energy, and outreach/education.

Since 2010, the GFT has evolved to include several active members of the fire community, including a service first (interagency) fire management specialist, incident business specialists, regional fire and aviation leaders, regional SusOps Coordinators, a hotshot member, a wilderness ranger, firefighters, and logistical support personnel. The vision of the GFT is to achieve "net zero waste, water, and energy at all large fire incidents by 2030 ," and the mission is to "integrate sustainability best management practices into the fire community."

In 2017, Shawna Legarza, current Forest Service National Director of FAM and a champion of sustainable practices within the wildland fire community, formed a partnership with the GFT, led

\footnotetext{
${ }^{3}$ Ibid.

${ }^{4}$ This Executive Order was revoked with the issuance of Executive Order 13693 (Planning for Federal Sustainability in the Next Decade) in March 2015. Subsequently, Executive Order 13834 (Efficient Federal Operations), issued in July 2018, revoked Executive Order 13693.
} 
at the time by Bobbie Jo Skibo, R10 SusOps Coordinator, and Dennis Fiore, R3 Fire Management Specialist. ${ }^{5}$ The intent of the collaborative partnership is to institutionalize the effort into the FAM organization and to ensure alignment between the intent of leadership and the implementation of pragmatic approaches on the ground.

The effort aims to build on past accomplishments that include a 2011 GFT article published in Fire Management Today; the launch of a plastic-bottle consumption reduction initiative, the establishment of a disposable-battery recycling program in R6 cache, the creation of a visibility campaign with a GFT graphic and stickers, and a delegation-of-authority letter highlighting the need for SusOps efforts to IMTs. ${ }^{6}$

The findings included in this report will be used to inform the development of strategies and actions to be implemented in the future.

\subsection{Project Background and Intent}

In 2015, the USFS requested assistance from the U.S. Department of Energy's (DOE's) National Renewable Energy Laboratory (NREL) in support GFT efforts. NREL is dedicated to advancing energy efficiency (EE) and renewable energy (RE) technologies and applications. Since its inception, NREL has supported the federal and private sectors in implementing EE and water efficiency (WE) systems and strategies to lower energy use and meet remaining energy needs with renewable resources while having minimal environmental impact. NREL has had a longstanding partnership with the USFS, having supported sustainability efforts for more than 15 years, including conducting net zero energy and water audits, greenhouse gas accounting and reduction efforts, RE project screening for the USFS portfolio of buildings, and others.

The USFS requested NREL assistance to identify and assess opportunities for reduction of energy and water use, waste generation, and associated costs, in fire operations. In 2015, NREL staff began work with USFS staff to identify ways to improve the efficiency of fire camp operations, including decreasing energy use, water use, and generated waste. This effort began with an exercise to understand fire operations and associated energy and water use, and waste generation. NREL staff participated in monthly calls with GFT members, researched related efforts in similar operations, and conducted a data call to gather relevant energy, water, waste, and other operational data. NREL staff had difficulties procuring data on operational energy or water use and cost, or waste generation associated with fire camp operations.

In 2016, NREL staff, in conjunction with USFS staff, determined that visiting fire camps would be the best way to understand the complicated logistical operations at fire camps and to begin gathering data while attempting to identify operational efficiencies that could be implemented to reduce energy and water use, and waste generation. NREL staff and GFT members visited six fires during the summers of 2016 and 2017. At each fire, they visited the Incident Command Post (ICP), the base camps, and a spike camp, in an effort to understand fire operations that relate to, are dependent on, or impact energy use, water use, and waste generation.

\footnotetext{
${ }^{5}$ Team leadership transitioned to Lara Buluç, R5 SusOps and Climate Change Coordinator, and Dennis Fiore, R6 Fire Management Specialist, in October 2018, after the writing of this manuscript.

${ }^{6}$ Greening Fire Team: 5 Year Strategy (draft).
} 


\section{Introduction}

This report summarizes work undertaken to understand and quantify fire camp operations' energy use, water use, and waste generation, and to identify opportunities for reduction. This scope included stationary (nontransportation fuels) energy use and costs, water use and costs, and waste generation and costs. By reviewing these data, combined with on-site observations gleaned from visiting multiple fire camps, best management practices can be identified to reduce the operational costs and increase the sustainability of operations at fire camps associated with energy and water use, and waste generation.

In 2015, staff from NREL began work with USFS staff to identify ways to improve the efficiency of fire camp operations, including decreasing energy use, water use, and generated waste. Initial work focused on understanding fire camp operations and logistics protocols, and quantifying energy use, water use, and waste generation, and associated costs. The intent of the 2015 effort was to gather this baseline data; fire camp visits were initiated the following summer (2016).

Beginning in 2015, NREL staff began participating in GFT calls and engaged with other members of the USFS fire community to gather needed data. A short survey was developed and sent to about 10 USFS staff members involved in fire camp operations (see Appendix A). Only two questionnaires were returned, and both were lacking information. NREL and USFS staff also gave a presentation on this effort and the associated data needs at the 2015 National Logistics meeting held in March 2015. After nearly a year of data-gathering efforts that failed to produce the requested information, the NREL assessment team determined that the baseline data that the team sought likely did not exist in a central repository or at the level of detail needed, and that it should proceed to the next stage of the study.

In 2016, NREL staff, in conjunction with USFS staff, determined visiting fire camps would be the best way to understand the complicated logistical operations at the camps and to begin gathering data, while attempting to identify operational efficiencies that could be implemented to reduce energy and water use, and waste generation. NREL staff and GFT members visited six fires during the summers of 2016 and 2017: the Cold Springs and Hayden Pass fires (Colorado, 2016), and the Highline, Boundary, Milli, and Whitewater fires (Arizona and Oregon, 2017). At each fire, they visited the ICP, the base camps, and a spike camp. The intent of the visits was to understand fire operations that relate to, are dependent on, or impact energy and water use, and waste generation. 


\section{Fire Camp Assessments}

The fires NREL and USFS staff visited in the summers of 2016 and 2017 are listed below and described in detail later in this section:

- Cold Springs Fire near Nederland, Colorado: July 13, 2016

- Hayden Pass Fire near Salida, Colorado: July 19-20, 2016

- Boundary Fire near Flagstaff, Arizona: June 19, 2017

- Highline Fire near Payson, Arizona: June 20, 2017

- Whitewater Fire near Sisters, Oregon: August 23, 2017

- Milli Fire near Sisters, Oregon: August 23, 2017

\subsection{Overview of Fire Camp Operations}

The term "fire camp" is used in multiple contexts in fire operations, sometimes in reference to all related incident logistical operations, and sometimes in reference to only portions. These operations encompass a central, congregating area for firefighting efforts; a location where crews eat, sleep, and refuel; and a location for operations, planning, logistics, and administration support staff to operate. Most fire operations have one ICP, a base camp, and spike camps; some fires have multiple base camps, and most fires have multiple spike camps. Every incident is different. In this document, the term fire camp refers to all related incident logistical operations, including the ICP, base camp, and spike camps.

The ICP is a location at which primary command functions for the incident are executed and may be collected with the incident base camp or other incident facilities. ${ }^{7}$ The ICP serves as the administrative headquarters for the support of the incident. Oftentimes, depending on the proximity of the fire to a town, the ICP is housed in a large, permanent structure with grid-tied energy and water services, such as a community center or school.

The base camp is a geographical site (or multiple sites) within the general incident area, equipped and staffed to provide sleeping, food, water, and sanitary services to incident personnel. ${ }^{8}$ The base camp could either be located in conjunction with the ICP or within a 1- to 2-hour drive time to the fire line and may or may not be tied to the grid. In the base camp, catering operations provide food for the crews; portable toilets are brought in; mobile washing units are used for showering, hand washing, and laundry; and most often, generators provide what little power is needed for light towers, water heating, and small electric loads (such as a laptop or air-conditioning unit in the medical tent). In most climates, crews sleep in personal tents. In very hot climates, crews sleep in conditioned spaces, if possible. This could be at the ICP, or a conditioned temporary structure (such as a sleeping trailer or yurt). The catering operations use significant amounts of energy for refrigeration and food preparation and are a contract service to the USFS; effecting change in those operations will require collaboration with contracting officers to modify or renew any contracts that incorporate recommendations from this report.

\footnotetext{
${ }^{7}$ National Wildfire Coordinating Group, "Glossary A-Z,” https://www.nwcg.gov/glossary/a-z\#.
} ${ }^{8}$ Ibid. 
Spike camps are satellites of the main fire camp and generally draw their supplies and food from the main base camp while providing their own sanitation facilities. Spike camps are used to support operation areas and minimize travel time for firefighters accessing the fire line, typically no more than 1 to 2 hours away from the base camp. Spike camps tend to be (but are not always) small, remote, fully off-grid operations for smaller crews. Often, food, water, and other supplies are driven or flown in. They are generally considered safety measures to prevent excessive fatigue and reduce the probability of a collision between a firefighting vehicle and a civilian vehicle or stationary object. ${ }^{9}$

\subsection{Logistical Considerations}

Assembling a fire camp is a considerable challenge that typically spans days. Many activities occur during this setup period, and because issues such as safety and functionality are primary concerns, issues related to greening fire camps necessarily become a secondary focus. Each incident and fire camp is unique, but many common activities occur during the planning and setup period, including:

- Siting:

- Identifying appropriate locations for the ICP, base camp, and spike camp(s), and negotiating and executing necessary land- and facility-use agreements, including access to energy, water, and wastewater services

- Catering services:

- Procuring catering services (a catering contractor provides all food, serve ware, and related infrastructure, such as cooking trailer(s), refrigerator trucks, generators, and fuel)

- Energy services:

- Grid-tied services are part of land- and facility-use agreements.

- Off-grid power supplies (usually diesel generators up to $100 \mathrm{~kW}$ ) are specified initially via a preorder list, and supplemental power supplies are procured, as needed, during the setup period.

- Light towers (or light carts) are prevalent in fire camp operations.

- Fuel for generators is supplied daily by fuel trucks from nearby communities.

- Water provision:

- Fire camp operations operating out of permanent facilities (schools, community centers) have access to water and wastewater services via land- and facility-use agreements.

- Operations occurring in open land areas have potable water brought in via trucks and provide services such as mobile showers, handwashing units, and laundry. Potable water taps can be used to fill canteens or water bottles, and bottled water is also provided.

- Portable toilets are provided to operations in open land areas.

${ }^{9}$ Ibid. 
- Waste management:

- Fire camp operations functioning out of permanent facilities have access to trash and, where possible, recycling and composting services.

- Operations occurring in open land areas usually have roll-off dumpsters for trash disposal; some incidents have dumpsters for recycling. The availability and use of small recycling receptacles and related signage vary by incident.

- Catering operations collect food waste, compostable utensils, plates, and cups in compostable bags, but often this waste is not composted.

- Internet service:

- The USFS has a contract with Verizon to provide cell tower boosters at no charge to the USFS in the event of an emergency.

The availability of services and supplies (e.g., tents, trailers, generators, latrines, catering) that are used in a fire camp can be limited depending on the site location and time of fire season. Fire camp supplies come from the local cache, as well as local suppliers, and can come from regional or even national stockpiles if the equipment is not available locally. Equipment is often ordered and used based on that which is readily and quickly available (e.g., more generalized equipment such as a light tower, rather than equipment with specific capacity such as a photovoltaicpowered LED light tower).

The availability of supplies in the caches is somewhat standardized but can vary from cache to cache (e.g., there might be only incandescent lights in one cache and LED lights in another cache). The USFS does a good job reusing equipment, tools, and supplies stored in the caches (e.g., tools such as shovels, axes, etc., will be put back into the local cache), but there may be an opportunity to standardize the caches and stock them with more sustainable options.

The Buying Team is responsible for purchasing supplies for the fire camps, and it has green purchasing guidelines and requirements. The Buying Team, however, commonly has difficulty with availability of green products, and there is typically a cost premium associated with green products. Currently, there is no mechanism for tracking green purchases and non-green purchases. The Buying Team has a spreadsheet for tracking purchases, and they could consider inserting a column into the spreadsheet to track whether products are green. Green purchasing guidelines and requirements should be further standardized so that the Buying Team has a clear understanding of what is required and what is available.

\subsection{Fire Camp Visits}

NREL staff visited six fire camps during the summers of 2016 and 2017. ICPs and base camps were visited at every fire; spike camps were visited when logistically feasible. At each site, NREL staff met with the Logistics Chief and Deputy Incident Commander to discuss GFT efforts and solicit feedback.

\subsubsection{Cold Springs Fire (Nederland, Colorado)}

The Cold Springs Fire was first reported on July 9, 2016, at 1:45 p.m., burning 2 miles northeast of Nederland, Colorado. On July 15, 2016, the Rocky Mountain Incident Management Team 
(IMT) Black transferred command of the fire to the Boulder County Type 3 IMT. ${ }^{10}$ NREL staff, escorted by Dennis Fiore (USFS), visited the ICP and the base camp of the Cold Springs Fire on July 13, 2016.

The ICP was operating out of the Nederland Community Center, and the base camp was sited in two fields about 1 mile outside of the town. The ICP was grid-tied for all utilities (electricity, water, and wastewater), and the base camp was off-grid. Minimal power was provided via small generators (about three), powering light towers and some ancillary loads (a fan and laptop in the medical tent). Handwashing stations (with heated water) were provided via a mobile trailer, and potable water was provided from a truck. No shower or laundry facilities were provided; crews used the nearby Nederland high school for these services and for sleeping (if on a daytime shift).

This was the first fire visited, and NREL staff spent a large amount of time meeting with staff from the IMT to learn more about the operations and logistics and walking around ICP and Base Camp. NREL staff did not receive any data during this site visit, but given the proximity of this fire to Golden, Colorado (where NREL is located), NREL staff are working to make arrangements to visit the unit offices and look through the fire box to determine what data are stored there.

\subsubsection{Hayden Pass Fire (Salida, Colorado)}

The Hayden Pass Fire, outside of Salida, Colorado, was ignited by lightning on July 8, 2016. On July 12, 2016, the local Type 3 organization transferred command of the Hayden Pass Fire to the Rocky Mountain Type 2 Blue Team (IMT). ${ }^{11}$ NREL staff, accompanied by Dennis Fiore, visited the Hayden Pass Fire on July 19-20, 2016; they visited the ICP, the base camp, and one spike camp. The ICP was operating out of Salida High School, and the base camp was situated on land adjacent to the Salida Ranger District office. Both locations featured sustainable elements: the high school is Leadership in Energy and Environmental Design Gold certified, and the USFS office has a large PV array, as seen in Figure 2.

\footnotetext{
${ }^{10}$ https://gacc.nifc.gov/rmcc/detailed ireport.php?year=2016\&incident=inc54 2016.log.
}

${ }^{11}$ https://gacc.nifc.gov/rmcc/detailed ireport.php?year=2016\&incident=inc55 2016.log. 


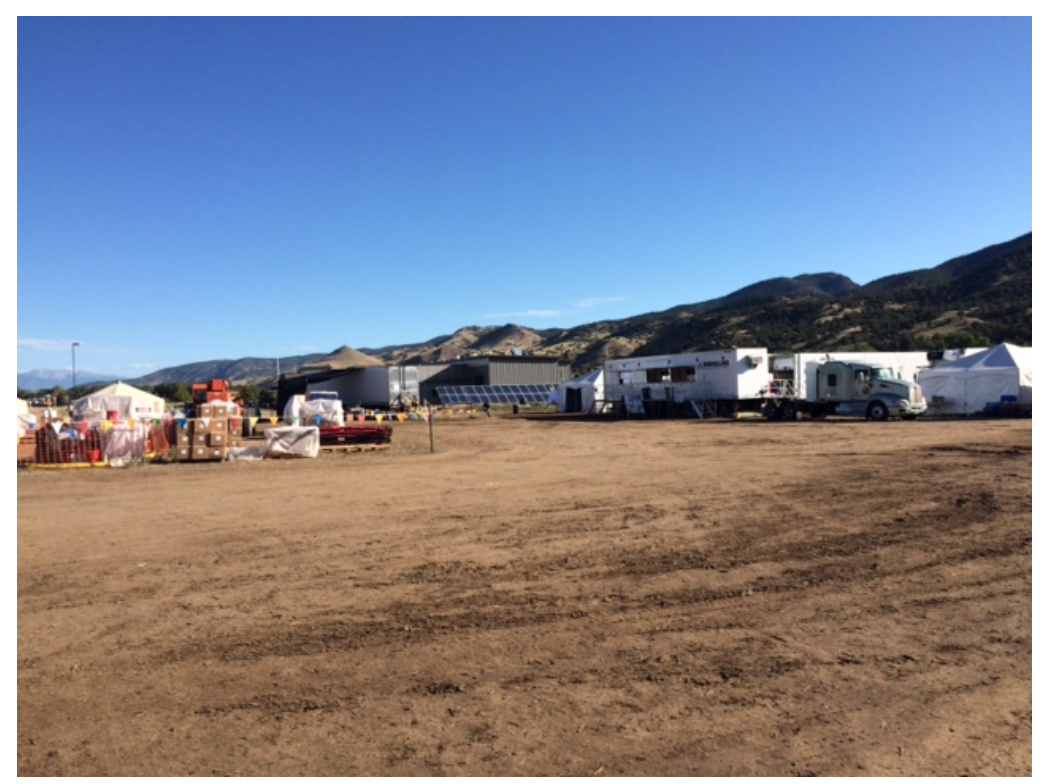

Figure 2. Base camp at the Hayden Pass Fire near Salida, Colorado

Photo by Alicen Kandt, NREL

The IMT operated out of the high school and mobile trailers that were transported to the high school; the trailers were powered by generators. The IMT members working out of the trailers preferred to work out of their own trailers, which housed their office equipment, rather than the high school.

The base camp included catering operations; a refrigeration ("reefer") truck; portable toilet, shower, and handwashing units (Figure 3 and Figure 4); portable laundry units; and personal tents.

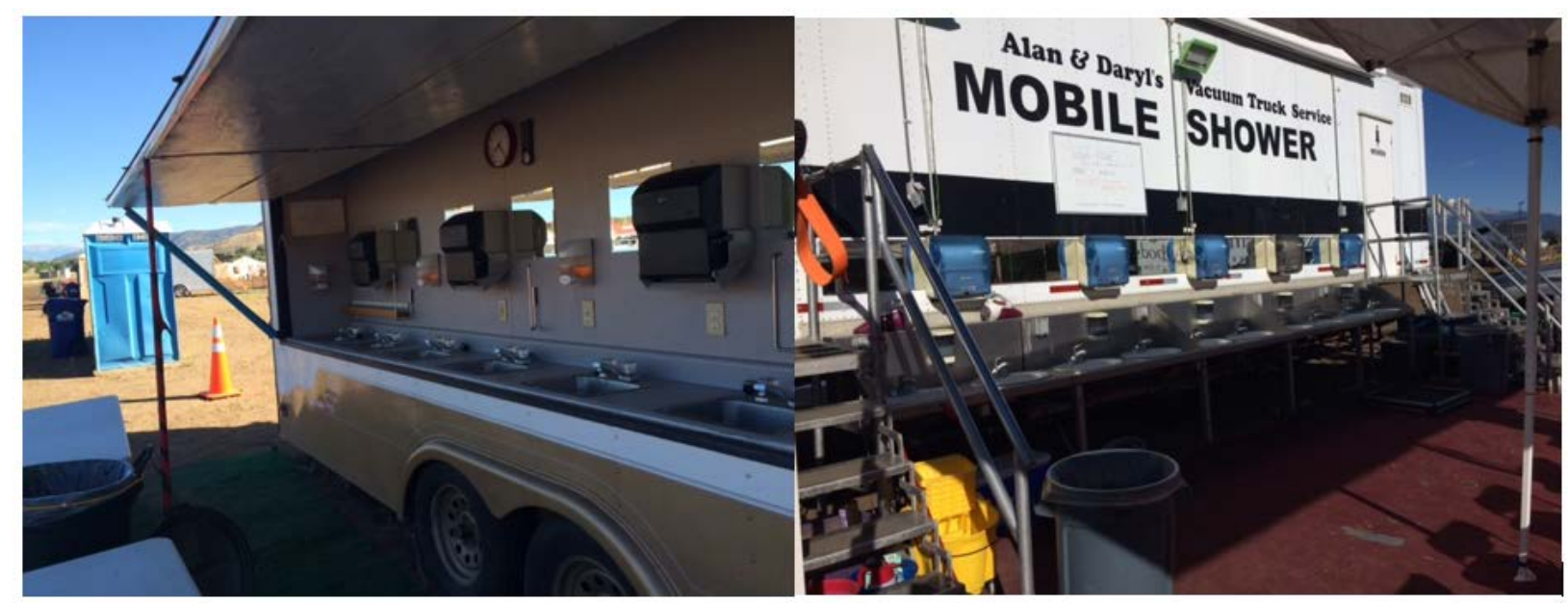

Figure 3. Handwashing and shower facilities at the Hayden Pass Fire

Photos by Alicen Kandt, NREL 


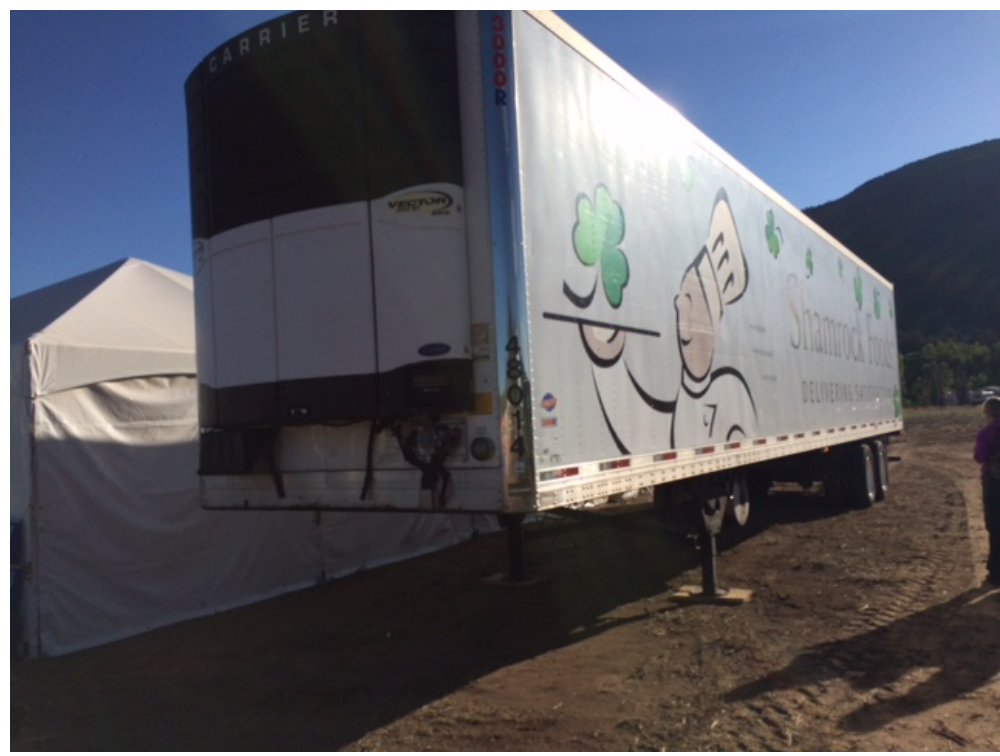

Figure 4. Reefer truck at the Hayden Pass Fire

Photo by Alicen Kandt, NREL

Approximate energy and water use information is provided in Table 2.

Table 2. Hayden Pass Fire Equipment Energy/Water Use ${ }^{12}$

\begin{tabular}{|l|l|l|l|}
\hline Equipment & Commodity & Quantity & Unit \\
\hline 5-kW Light Cart & Diesel & 15 & Gallons/day \\
\hline Reefer Van & Diesel & 15 & Gallons/day \\
\hline Shower Trucks & Diesel & 15 & Gallons/day \\
\hline Shower Trucks & Potable Water & 2,000 & Gallons/day \\
\hline Water Pumps & Potable Water & 4,000 & Gallons/day \\
\hline
\end{tabular}

\subsubsection{Boundary Fire (Flagstaff, Arizona)}

The Boundary Fire, outside of Flagstaff, Arizona, was ignited by lightning on June 1, 2017. NREL staff, escorted by Dennis Fiore (USFS), visited the Boundary Fire on June 19, 2017; photos from the assessment are provided in Figure 5. At the time of the audit, there were 435 people working the fire. The base camp was located at a fairground, and electricity to the site was provided by diesel generators. The major power users at the site included office equipment, interior space lighting, site lighting, reefer trucks, and food catering operations. Diesel-powered light carts with incandescent lights were used for site lighting; most of these lights operated from 7 p.m. to 10 p.m., although a select few light carts remained on all night for safety reasons. A fuel truck topped off the five diesel generators, the refrigerated trucks, and light carts daily. The estimated fuel use at the site was 106 gallons per day.

\footnotetext{
${ }^{12} 847$ total personnel on July 19, 2016.
} 

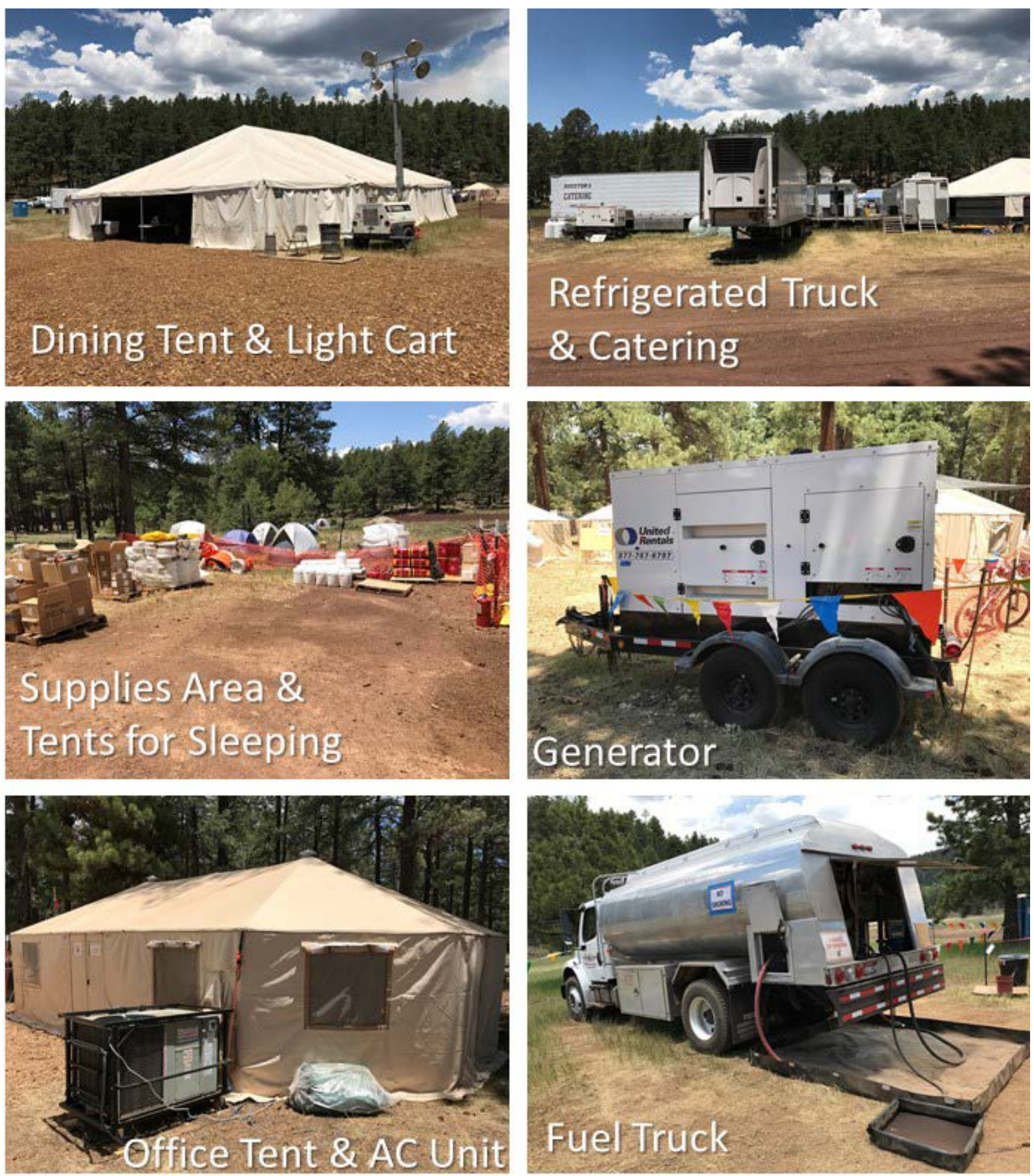

Figure 5. Boundary Fire Camp near Flagstaff, Arizona

Photos by Jimmy Salasovich, NREL

Uninsulated rented tents were used for meeting/office space and dining. These tents had typical office equipment and compact fluorescent (CFL) and incandescent lighting. Power for airconditioning, lighting, and other end-uses in the tents was provided by diesel generators, and typically three tents were operated off of one generator. Personal tents set up in open fields were used for sleeping. Portable toilets, handwashing stations, and showering units were set up 
throughout the site. A bulk water truck provided water to the site at an average rate of 2,250 gallons per day.

At the time of the audit, the caterer was providing 500 hot breakfasts and dinners per day and 500 cold (sack) lunches per day. Compostable tableware, cups, and silverware were used and disposed of in compostable bags, but this waste was not being composted. Only an estimated 5\% of the waste generated at the site was recycled. A member of the catering team said that the caterer tries to minimize food waste when possible and has donated excess food in the past. The catering contractor indicated it would comply with any recycling standards required by the USFS. The catering operations used about 25 gallons of diesel per day for refrigeration and 25 gallons of propane per day for cooking.

A significant portion of the audit involved discussions with personnel working the fire. Every person the audit team spoke with believed having a Sustainable Operations Coordinator assigned to a fire camp would be an effective way to help make fire camp operations more efficient and sustainable.

A general feeling prevailed that recycling at the site could have been better if they had more time setting up the fire camp. People were generally open to using recycling bins for paper, cardboard, plastic, aluminum, and glass if they were provided, but there were cultural barriers to recycling with some people fighting the fires. One idea was to have hotshot crews take the lead on recycling, given their elevated status at fire camps. Furthermore, great progress has been made in getting people to wash their hands prior to eating, which suggests cultural changes are possible at fire camps. Battery use was closely connected to battery-powered radios, and there was no battery recycling at the site. People were open to battery recycling, and they were also open to the idea of moving toward rechargeable radios. In general, people were open to providing 5gallon water containers ("cubies") along with standard bottled water so that people had a choice and an opportunity to reduce waste associated with bottled water.

The audit team met with the Buying Team, which had a standardized spreadsheet for purchasing. The people on the Buying Team were required to take a green training and purchase locally when available. The Buying Team suggested urban vehicles could be hybrids in most cases, and they reported consolidating delivery trips to the site when possible. The Buying Team did specification refreshes where working groups got together and updated specifications for procuring needed supplies.

\subsubsection{Highline Fire (Payson, Arizona)}

The Highline Fire near Payson, Arizona, originated on June 10, 2017. ${ }^{13}$ NREL staff, escorted by Dennis Fiore, visited the Highline Fire on June 20, 2017; photos from the assessment are provided in Figure 6. The audit team visited the base camp and the Sharp Creek Campsite located 25 miles from the base camp. Located at a campground, the base camp had very limited space. Electricity to the site was provided by diesel generators. The major power users included office equipment, interior space lighting, site lighting, reefer trucks, and food catering. Dieselpowered light carts with incandescent lights were used for site lighting, and most of these lights operated from 6 p.m. to 10 p.m., except for a select few light carts that remained on all night for

\footnotetext{
${ }^{13}$ https://inciweb.nwcg.gov/incident/5233/.
} 
safety reasons. The five generators, six light carts, and one reefer truck at the base camp used about 200 gallons of diesel per day. A fuel truck topped off the diesel generators, refrigerated trucks, and light carts daily at both the base camp and the Sharp Creek Campsite.
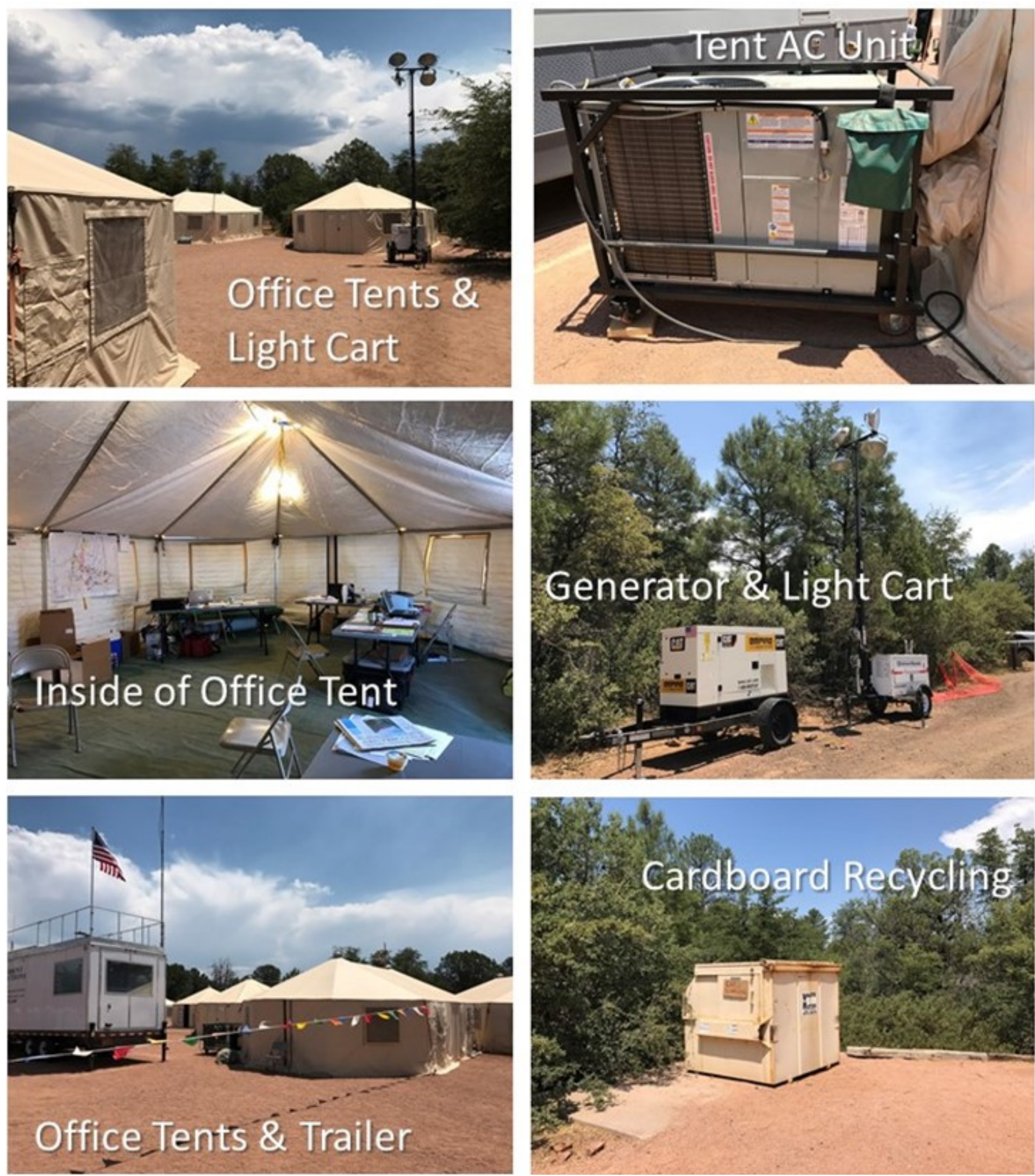

Figure 6. Highline Fire Camp near Flagstaff, Arizona

Photos by Jimmy Salasovich, NREL

Insulated rented tents were predominantly used for meeting/office space and dining (see Figure 7). These tents had typical office equipment and CFL and incandescent lighting. Power for air- 
conditioning, lighting, and other end-uses in the tents was provided by diesel generators, and each tent would typically draw 30 amps of power given the high air-conditioning load. Personal tents set up in open fields were used for sleeping space, and portable toilets, handwashing stations, and showering units were set up throughout the site. A bulk water truck provided water to the site.

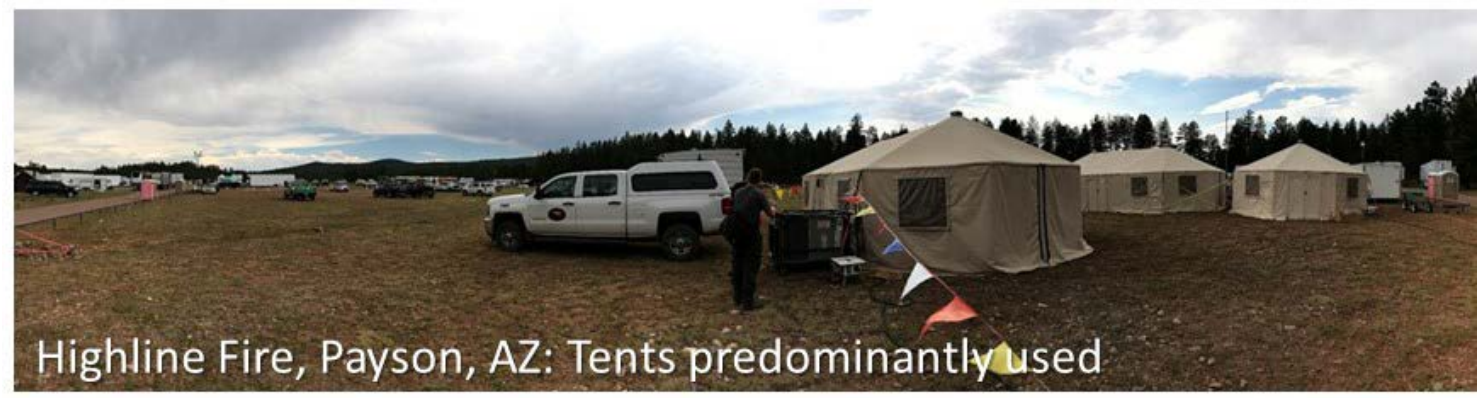

Figure 7. Highline Fire

Photo by Jimmy Salasovich, NREL

The caterer provided hot breakfasts and dinners and cold lunches to everyone working the fire. Except for cardboard, there was no recycling at the site due to how quickly the site was set up. The logistics coordinator noted that most of the sites that he had previously worked at did provide recycling. The caterer noted that it would be very difficult to provide 6,000 calories/day meals for fire fighters and 2,000 calories/day meals for nonfirefighters working the fires. They tried to provide two meal sizes in the past, and it was too much to manage. The site staff noted that food waste is always an issue, and although they donate some of the packaged lunch food to charities, most of the excess food is wasted because things are so dynamic. The staff also noted that the bottled water and sports drinks never get wasted.

Personnel at this site were more outspoken than other sites that were visited with regard to the importance of providing water bottles. The personnel noted that "cubies" are only good for 3 days once they are filled, but people use them for longer. Cubies are also only supposed to be used once and are not supposed to be refilled, but people refill them. It was stated that the potential issues with using bulk water for drinking is huge given that in the past 1,000-person camps have had to shut down because of water contamination.

\subsubsection{Whitewater Fire (Bend, Oregon)}

The Whitewater Fire near Bend, Oregon, originated on July 23, 2017. ${ }^{14}$ NREL staff, escorted by Dennis Fiore, visited the Whitewater Fire on August 23, 2017; photos from the assessment are provided in Figure 8.

The base camp was located at the main lodge of the Hoodoo Ski Area, and although a majority of the electricity to the site was provided by the local electric utility, there were also some diesel generators providing electricity to the operations. The major power users at the site included office equipment, interior space lighting, site lighting, refrigerated trucks, and food catering. Four diesel-powered light carts were used for site lighting, and most of these lights operated from 6 p.m. to 10 p.m., except for a select few light carts that remained on all night for safety. It should be noted that one of the light carts had LED lights, as opposed to the standard

\footnotetext{
${ }^{14}$ https://inciweb.nwcg.gov/incident/5420/.
} 
incandescent light carts typically found throughout fire camps. (A photo of the LED light cart is included in the photo montage below; note how much smaller the associated generator is for this light cart, given that LEDs are much more efficient than incandescent lighting.) Often, the generators for the standard light carts were used to power equipment other than the lights. Those working at the site were satisfied with the operation of the LED light cart. A fuel truck would periodically top off the diesel generators, the refrigerated trucks, and light carts.
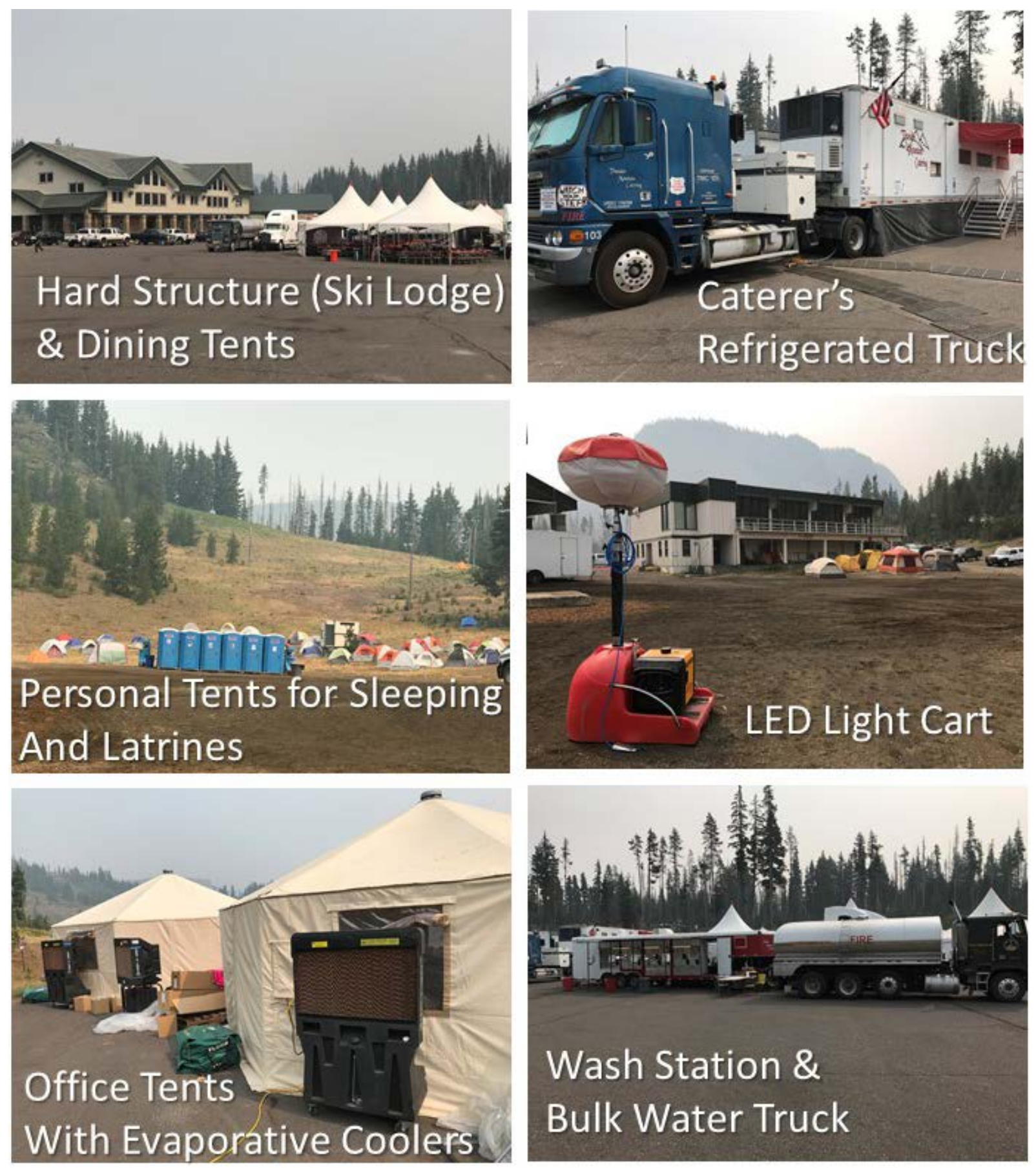

Figure 8. Whitewater Fire Camp near Bend, Oregon

Photos by Jimmy Salasovich, NREL 
The main lodge of the Hoodoo Ski Area was used for meeting/office space and dining. Uninsulated, rented tents were also used for office space, and the tents were equipped with five 100 -watt incandescent lights and evaporative coolers. Personal tents set up in open fields were used for sleeping space, and portable toilets, handwashing stations, and showering units were set up throughout the site. A bulk water truck provided water to the site.

At the time of the audit, the caterer was providing 500 hot breakfasts and dinners per day and 500 cold lunches per day. The caterer used about 100 gallons of diesel per day, purchased from the site fuel truck. The caterer used about 2,000 gallons of bulk water per day, including water used for the kitchen and wash stations. Propane was used at a rate of 100 gallons per day in the kitchen. The refrigerated trucks used about 30 gallons of diesel per day.

USFS hired a vendor to handle recycling; photos related to the recycling operation are provided in Figure 9. The recycling vendor charged $\$ 2,400$ per day. Hiring a vendor for recycling is not commonly done at fire camps, but Whitewater site personnel felt very positive about recycling. At this fire, waste was reduced by an estimated $40 \%$ due to recycling.

The site staff were unable to compost, although the vendor estimated it could achieve up to $70 \%$ waste reduction with composting. The USFS criteria for net zero waste is $100 \%$ reduction in waste sent to the landfill via reduction in waste generation and reuse and recycle. ${ }^{15}$ A $20 \%$ waste reduction can typically be achieved by providing bottle and cardboard recycling, $40 \%$ can be achieved by hiring a recycling contractor, and $70 \%$ can be achieved by recycling and composting. On the food side, all waste generated at the Whitewater site could have been composted except for the silverware wrapper.

The staff at the fire camp found that recycling is contagious, and it helps that recycling bins are nice and well-designed. Deschutes County, where this fire occurred, has well-established, effective infrastructure for recycling. Kelly Jaramillo (USFS Southwestern Region Sustainable Operations Specialist) did a comparison of the true cost of hiring a camp crew to recycle versus hiring a vendor, and it showed that the cost of contracting recycling services is close to and sometimes cheaper than using in-house resources.

The Whitewater site offered battery recycling, and the staff estimated that $30 \%$ of batteries were being recycled. AA batteries were used most commonly at the site, primarily for radios. At the time of the audit, which was conducted a month after the fire started, the site had used 80,000 AA batteries and had ordered an additional 80,000. Site personnel generally felt there was a need to move toward using rechargeable lithium-ion battery radios, noting that Alaska crews currently use rechargeable radios with good success. More information on the use of rechargeable batteries in handheld devices can be found in the USFS National Technology and Development Program publication "Hand-held Devices: Recharging Batteries in the Field." 16

\footnotetext{
${ }^{15} \mathrm{https}$ ://www.fs.fed.us/sites/default/files/factsheets-netzero.pdf.

${ }^{16}$ Ted Etter and David J. Plummer, Hand-held Devices: Recharging Batteries in the Field (Missoula, MT: U.S. Department of Agriculture, Forest Service, National Technology and Development Program, 2011), https://www.fs.fed.us/t-d/php/library_card.php?p_num=1166\%202314.
} 

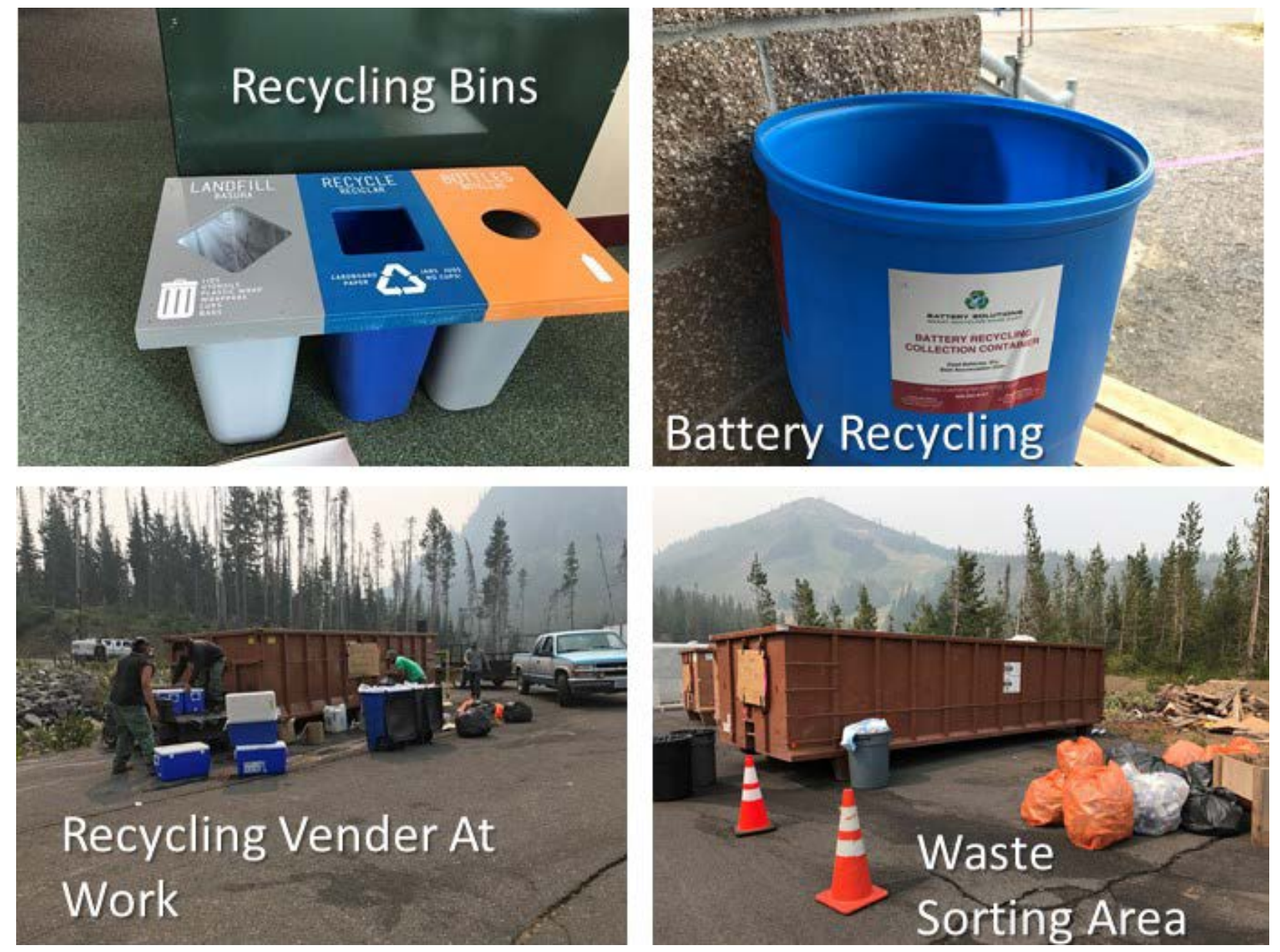

Figure 9. Whitewater Fire Camp recycling operation

Photos by Jimmy Salasovich, NREL

The site was using a solar-powered radio repeater (004080 Solar Panel Kit). Photos of the solarpowered radio repeater are provided in Figure 10. Site personnel had positive feedback regarding using the solar-powered radio repeater kit, reporting that it worked well in remote locations, because it is built to withstand the harsh environments found in the field. They also noted that combining this kit with a lead-acid battery to extend the operating hours is good practice. Specifications for the Solar Panel Kit can be found in the National Incident Radio Support Cache User's Guide. ${ }^{17}$

\footnotetext{
${ }^{17}$ National Incident Radio Support Cache User's Guide (Boise, ID: National Interagency Fire Center, 2018), https://www.nifc.gov/NIICD/docs/2018\%20NIRSC\%20Users\%20Guide\%20Web.pdf.
} 

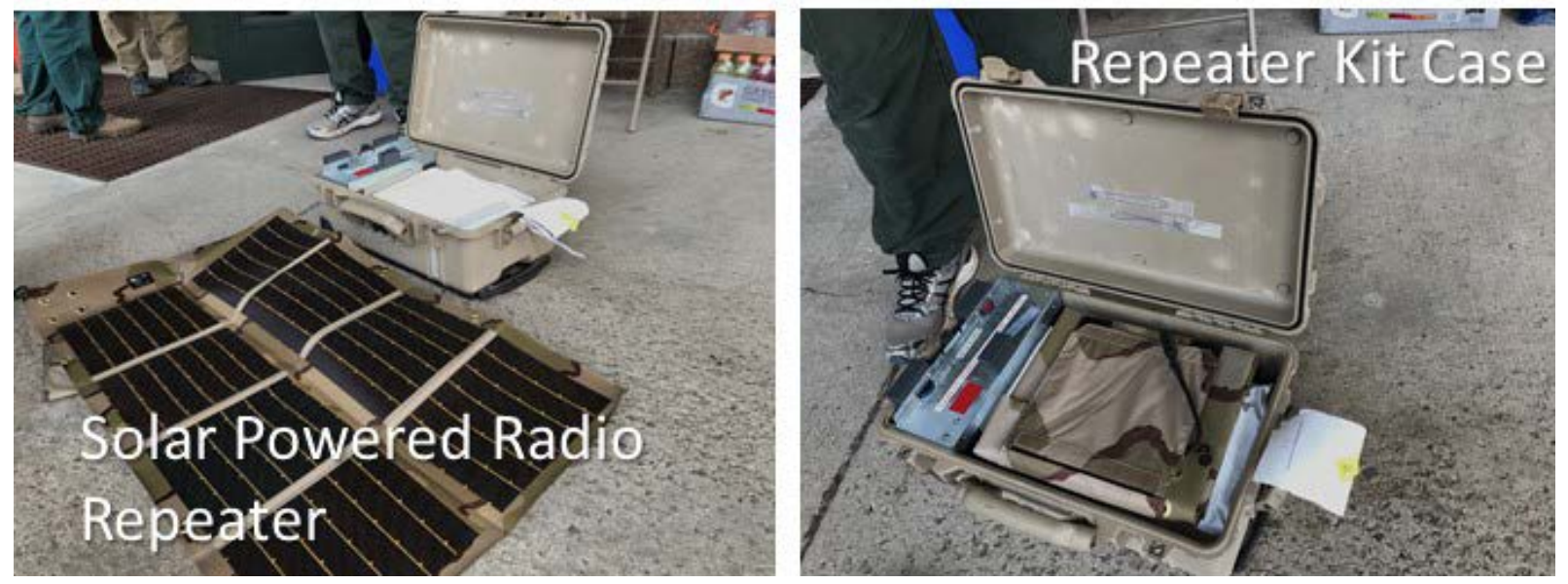

Figure 10. Whitewater Fire Camp solar-powered radio repeater

Photos by Jimmy Salasovich, NREL

\subsubsection{Milli Fire (Sisters, Oregon)}

The Whitewater Fire near Sisters, Oregon originated on August 11, 2017. ${ }^{18}$ NREL staff, escorted by Dennis Fiore, visited the Milli Fire on August 23, 2017; photos from the assessment are provided in Figure 11. Similar to the Boundary Fire, the base camp was located at a fairground, and electricity to the site was provided by diesel generators. The major power users at the site included office equipment, interior space lighting, site lighting, refrigerated trucks, and food catering. Diesel-powered light carts with incandescent lights were used for site lighting, and most of these lights operated from 7:00 p.m. to 10:00 p.m., while a select few light carts remained on all night for safety. A fuel truck topped off the diesel generators, the refrigerated trucks, and light carts daily.

\footnotetext{
${ }^{18}$ https://inciweb.nwcg.gov/incident/5517.
} 

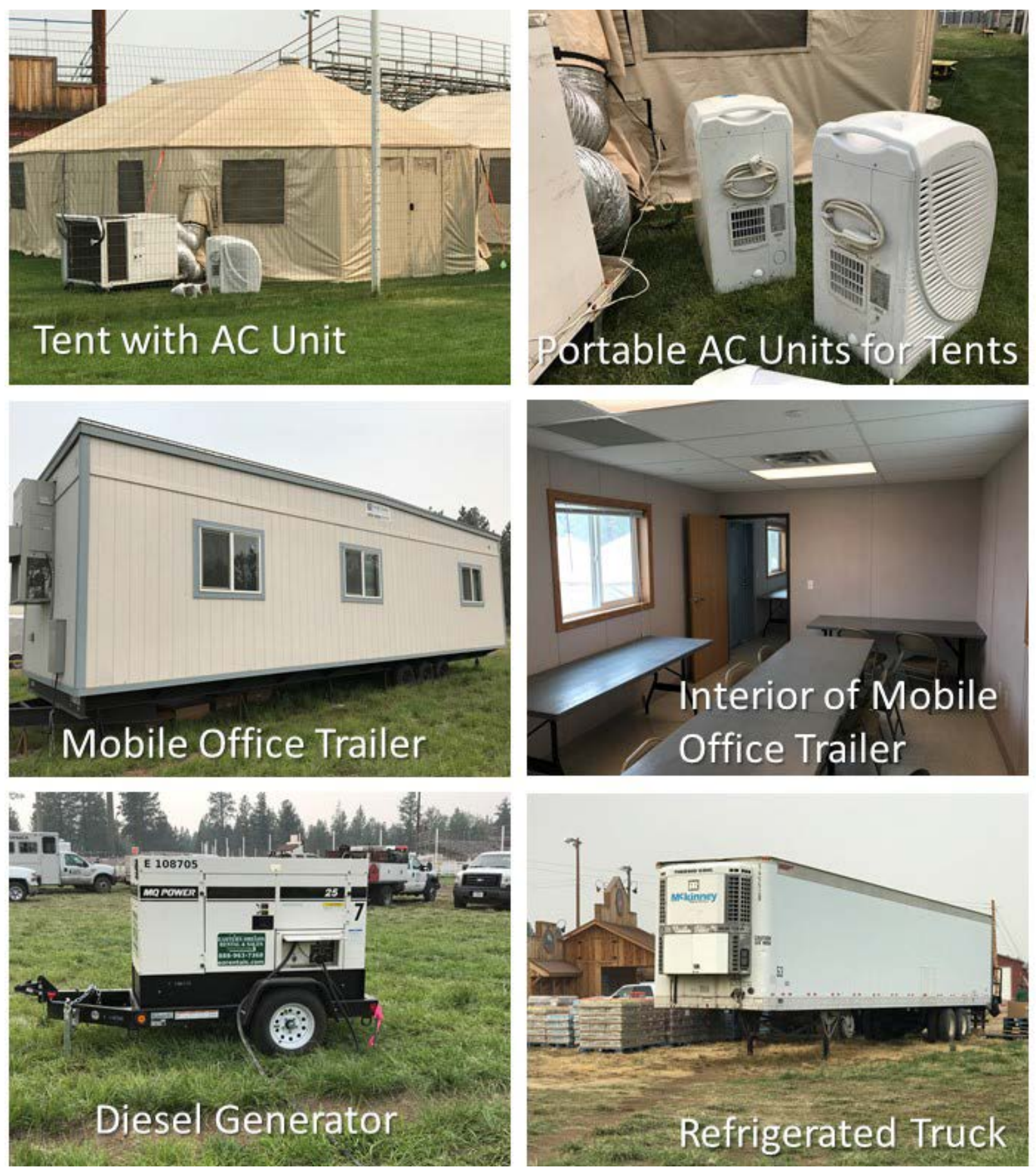

Figure 11. Milli Fire Camp Near Sisters, Oregon

Photos by Jimmy Salasovich, NREL 
Rented uninsulated tents were used for meeting/office space and dining. These tents had typical office equipment and CFL and incandescent lighting. Power for air-conditioning, lighting, and other end-uses in the tents was provided by diesel generators. Four mobile office trailers were also used at the site at the time of the audit, and these trailers had standard air-conditioning units with linear fluorescent lighting. Personal tents set up in open fields were used for sleeping space; portable toilets, handwashing stations, and showering units were set up throughout the site. A bulk water truck provided water to the site.

The caterer provided hot breakfasts and dinners and cold lunches each day for everyone working at the fire. There was some recycling taking place at the site (managed by site personnel), and site personnel were very interested in having a recycling vendor provide recycling services.

The Milli Fire was the only site that the audit team visited that used mobile sleeper trucks (see Figure 12). The mobile sleeper trucks can sleep 42 people, and each person has an individual storage area. Powered by $16.5-\mathrm{kW}$ generators, the sleeper trucks are self-sufficient as far as electricity goes; they have air-conditioning units and humidifiers and are sanitized two times a day.

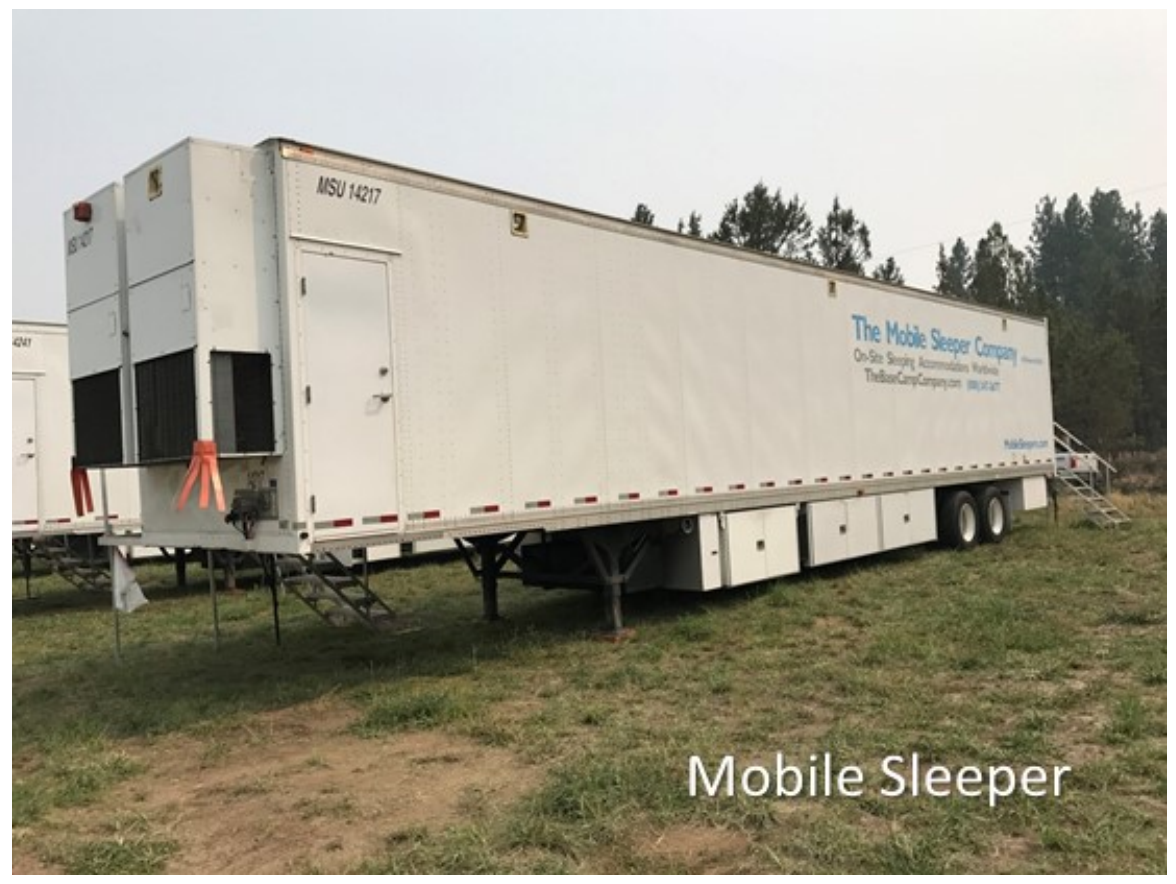

Figure 12. Milli Fire Camp mobile sleeper truck

Photo by Jimmy Salasovich, NREL 


\section{Observations}

The many insights gleaned from the six fire camp visits conducted in 2016 and 2017 were invaluable for NREL staff seeking to understand fire camp operations and begin to identify potential best management suggestions and opportunities.

\subsection{Current Best Practices}

The suggested best practices, including many observed during the visits to the fires, are listed below.

- Championing of sustainability: In general, most USFS staff and IMTs were highly motivated to incorporate sustainable measures into incident operations. Site champions will be influential in moving sustainable initiatives forward in the future, and it was very encouraging to encounter so many supportive staff and crews while visiting the fires. People generally embraced sustainability and conservation; for instance, they were observed turning off lights and air-conditioning when leaving tents.

- Composting: Current practices and contracting requirements ensure that catering contractors provide compostable utensils, plates, and cups, and collect these items and food waste in compostable bags. This is an effective first step in implementing composting in fire camp operations.

- Recycling: Some fire camps had comprehensive recycling options, including cardboard, plastics, glass, and even batteries. One camp contracted out these services to a vendor, resulting in a large increase in recycled materials and minimizing the burden to USFS staff associated with coordinating recycling efforts.

- Canteens: The use of canteens, or cubies, was broadly encouraged and often adopted. Potable water taps are provided on all fires, and the use of cubies helps reduce the plastic waste generated from plastic bottle use.

- Electrolyte powder: Some fire camps were piloting the use of electrolyte powder, which can be added to water in cubies, thus further reducing plastic waste generated from electrolyte (sports) drink plastic bottle use.

- Greening Fire Team efforts: The GFT worked to communicate opportunities to the fire community for making fire operations more sustainable, including the promotion of "Greening Fire Tips" (Appendix B) and the distribution of GFT stickers.

- Solar-powered radio repeater: One fire camp deployed a solar-powered radio repeater and indicated it was very effective. Adding a lead-acid battery further extended the operating hours, and the system was built to withstand harsh elements found in the field.

- Rechargeable battery radios: The use of radios with rechargeable lithium-ion battery has the potential to drastically reduce battery waste. This technology is already being effectively deployed in Alaska.

- LED lights: LED lights were observed in some fire camps, including light towers and tent lighting. LEDs are much more efficient than the incumbent incandescent lighting.

- Reuse and recycling at caches: Personnel at the various fires indicated that many of the tools and equipment taken from the main cache and used to fight a fire are reconditioned and reused for future fires. Recycling also occurs at the main cache. 


\subsection{Challenges and Constraints}

The biggest challenge associated with this work effort is the lack of baseline data. Generally, when conducting an audit and trying to identify and quantify savings opportunities, the first step is to establish a baseline. For this effort, that would include energy and water use and cost and waste generated, as well as waste disposal costs. Currently, there is no central repository of costs expended on energy and water services or on waste removal in fire operations. There is also no collection of data on energy and water use, or waste generation in these operations. NREL researchers met with USFS financial staff on the IMTs and were not able to procure this information. It became apparent that although costs expended on firefighting operations are tracked daily during a fire, those costs are not categorized by expenditure type. These data would be useful to help justify the importance of sustainable measures, and it is necessary to quantify the value of such efforts.

Another constraint is that the mission associated with fire camp operations often pushes SusOps to a secondary consideration. Identifying sustainable practices that can be incorporated into the everyday operations in a way that is seamless and ingrained in operational practices will enable sustainability to become commonplace without adding burden or creating distraction for IMTs. 


\section{Best Management Suggestions}

The current best practices listed above should be examined for opportunities for replication, improvement, or standardization, then broadly expanded to fire camp operations for widespread adoption. Other suggested best management practices are provided below.

\subsection{Coordination}

\subsubsection{Sustainable Operations Coordinator for Every Incident}

Currently, a coordinated approach to SusOps is lacking in IMTs and fire camp operations. Providing a dedicated staff person at each fire camp who is fully responsible for promoting and implementing sustainable actions (e.g., identifying what recycling and composting infrastructure is available in the community; setting up recycling/composting; coordinating recycling/composting pickup; communicating recycling/composting processes to staff in base camp and ICP; identifying local community foodbanks or relevant organizations for food donation; and researching the local availability of alternative generation technologies, such as photovoltaic-powered light towers and solar-powered water heating for shower and hand washing) could result in drastic energy, water, waste, and associated cost savings.

Next steps and additional considerations: Thought should be given to determining the best skill set for this position; outlining the duties, expectations, requirements, and resources associated with this position; and identifying how this person would fit organizationally within the IMT, when the coordinator would be deployed to the incident, and how long they would need to stay on-site. The Sustainability Coordinator Checklist drafted in 2016 could serve as a starting point for this process.

\subsubsection{Centralized and Standardized Data Collection of Metrics}

One of the biggest challenges associated with this work effort was the lack of baseline data. Developing metrics and procedures for collecting data, as well as a centralized repository for this data, will help facilitate quantification of energy and water use, and waste generation, as well as associated costs, from fire camp operations. These data can then be used for identifying and quantifying savings opportunities, as well as comparing the efficiency of one incident's operations to another. These data could also be used for further study of potential savings, including investigating the correlation between a variety of factors, such as cost, incident type, total personnel, energy use, water use, and waste generation.

Next steps and additional considerations: Consider building on the survey in Appendix A to outline a list of data needs. Work with IMTs to better understand what level of detail is collected versus what level of detail is desired and try to determine whether additional data could be collected and at what level of effort. Consider working to procure the fire box documents from one of the previously visited fires to delve deeper into what data are collected. Investigate options for a central repository of related energy, water, and waste use and cost data, including examining what other agencies and entities (Department of Defense, Bureau of Land Management, and state and local organizations) use for reporting and tracking such information. 


\subsubsection{Continued and Expanded Greening Fire Team Efforts}

The GFT has been effective at initiating dialogue regarding the potential to incorporate sustainable practices into incident operations. They have successfully communicated Greening Fire Tips (Appendix B) and promoted their work via stickers and other education and outreach materials. Continued support for the GFT should be provided by the USFS. GFT members should also examine ways to expand their impact, not only within USFS operations but to the broader incident response community, including other federal agencies, as well as state and local entities.

Next steps and additional considerations: The GFT has worked to disseminate findings from this and related efforts to others within the broader incident response community, including potentially creating a publicly available website or publishing relevant findings. The GFT could work to create a mechanism to share lessons learned with other related stakeholders, such as a working group or annual meeting. The GFT should continue trying to leverage related efforts and research conducted by other entities such as the Department of Defense and Department of Homeland Security.

\subsection{Energy Reduction}

\subsubsection{Use of Permanent Structures When Possible}

Fire camp operations use a variety of structures, primarily driven by what is available in the area. These include permanent structures, such as schools or community centers, as well as nonpermanent structures such as yurts, tents, or trailers. Generally, permanent structures are better insulated, higher performing, and less energy-intensive than non-permanent structures. An energy analysis was conducted to compare the energy-use intensity (EUI) of tents, mobile office trailers, and hard (permanent) structures. The results of the analysis are presented in Appendix C, but the findings indicated that tents have the highest EUI, followed by mobile office trailers, and then, hard structures. This indicates that when hard structures are available, they have the lowest EUI; they also provide the added benefits of not having to contend with dust intrusion and having grid power. For optimal energy use and associated costs, the ICP should be sited in an efficient, permanent structure. When comparing tents to trailers, the trailers have a lower EUI and should be considered in cases where trailers are available at a comparable cost to tents. Hybrid solutions, where a permanent structure is procured for the ICP but portions of the IMT operate out of mobile trailers or tents, should be avoided unless necessary due to space or other constraints.

Next steps and additional considerations: Consider including building vintage and efficiency as part of the site selection process associated with selecting a location for the ICP. Investigate opportunities to educate IMTs about the benefits of using permanent structures (when available) instead of mobile trailers or tents.

\subsubsection{Potential Use of Solar Energy Systems}

Minimal use of renewable energy systems was observed in fire camp operations. Small, portable photovoltaic or solar thermal systems have the potential to be cost-effective, resilient, and broadly applicable in these operations for such end uses as powering light towers or water pumps; providing hot water for handwashing stations, shower facilities, and phone charging 
stations; and recharging radio batteries. For example, the Whitewater Fire IMT used a solarpowered radio repeater and expressed support for the system. Mobile photovoltaic systemssuch as the trailer-mounted system used by the National Park Service in Yellowstone National Park, which combines 9-MW photovoltaics (PV) with a generator and batteries - could be used to power larger electrical loads and could be moved to wherever power was needed and from incident to incident. ${ }^{19}$

Next steps and additional considerations: Examine the potential to add PV-powered light towers to fire caches, and to specify these systems as a priority over standard generator light towers, when light towers are ordered from suppliers (i.e., not procured by the cache). Also consider specifying PV or solar thermal-powered handwashing or shower facilities over standard, generator-powered ones. Conduct a cost-benefit analysis of these alternative options (PV-powered light towers and PV- or solar thermal handwashing and shower facilities) versus standard generator-powered systems. Consider procuring a mobile PV system and piloting it at numerous incidents throughout a fire season. Conduct a cost-benefit analysis of the mobile PV system and interview system users regarding ease of use, maintenance requirements, and other lessons learned.

\subsubsection{Potential Use of Mobile Biomass Systems}

Mobile waste disposal has been an area of interest for many years. Research in biomass has looked at smaller mobile systems that can process small-diameter timber or help with cleanup after infestations such as the pine beetle. Disaster relief efforts have initiated research into small systems that can process wood waste, as well as hurricane debris, and generate power where it is badly needed. Companies have tried to develop small systems that can process waste from remote communities, military bases, forward operating bases, island communities, and others. Some systems target construction and demolition debris, infectious waste, and document waste.

Many systems have been developed to some degree, but no company has captured a large market share, primarily due to a few key challenges. First, the term is waste to energy (WTE), and the energy portion is difficult. A system could process waste and generate electric power, but there are issues with locating the system near power lines, then getting the permission required to tie into a utility grid system. Another form of energy is thermal energy. A waste system can generate heat, which is typically in the form of hot water. Without this energy-generation aspect, the systems are purely incinerators, which have their place, but do not generate the same level of interest as do actual WTE projects.

The primary technologies assessed are combustion, gasification, anaerobic digestion, and composting. Combustion systems typically require a substantial scale to make economic sense and are not very efficient. In waste disposal applications, energy-generation efficiency is not always the primary concern, because disposal is the key driver. However, investing large amounts of capital into a system that is difficult to be mobile for a small amount of electricity is a challenge and would not be suitable for campsites.

${ }^{19}$ Case Study: Mobile Photovoltaic System at Bechler Meadows Ranger Station, Yellowstone National Park (Washington, DC: U.S. Department of Energy), https://www.energy.gov/sites/prod/files/2014/03/f8/60516.pdf. 
Gasification can be attractive, as the waste material is turned into a combustible gas that is fed into a gas engine to make power. Gasifiers are very sensitive to waste-stream quality, however, and they perform better when they have a more uniform, heterogenous waste stream. Biomass can be a good fuel, although most gasifiers require a very dry, woody feedstock. Gasifying mixed waste is a challenge. A gasifier waste stream is normally free of metal, rocks, and dirt, and must be shredded to an appropriate size. Some gasifiers are more forgiving because they do not rely on material moving through the system using gravity; instead, they use fluidized beds or rotary kilns (which look like cement mixers). Additionally, for a mixed waste containing plastics, advanced pollution control systems are needed to clean up the emissions, which can add cost and complexity. Small-batch gasification systems are used in specific applications. One example is the Micro Auto Gasification System (MAGS) that can treat a variety of waste streams. ${ }^{20}$

The most likely options for fire camp applications would be anaerobic digestion or composting. Waste from the fire camp applications typically consist of cardboard, plastics from water bottles, and food waste. There is also waste from plates, utensils, etc., although the USFS requires that these be compostable. Additionally, compostable bags are used for food waste and other compostables, although bags filled with compostable materials are often thrown into the trash. If organic waste could be collected separately from other waste, then a centralized digester could be installed. Generated gas could be flared or used to supply heat. Composting would be the simplest approach and the easiest to initiate. This is not a new concept. Yosemite National Park has diverted much waste from landfills while cutting disposal costs. ${ }^{21}$ The organic waste is collected and hauled to a composting facility. A number of companies also provide small composting bins that could be located at fire camps to process organic food waste and compostable products.

Next steps and additional considerations: Consider a waste stream analysis (waste audit) at one or more incidents to define the waste composition and quantity. Investigate potential opportunities to pilot a biomass technology at an incident.

\subsubsection{Use of LED Lights}

Many incandescent lights were observed in use in fire camp operations, including in dining tents and in light towers. LED lights are much more efficient than the incumbent incandescent lighting. LED lights should be listed as a priority request for all lighting applications, when available.

Next steps and additional considerations: Examine the potential to add LED light towers to fire caches and to specify these systems as a priority over standard incandescent light towers when light towers are ordered from suppliers. Conduct a cost-benefit analysis of LED light towers versus standard incandescent light towers. Also, investigate the potential to specify LED lights in all other lighting applications in nonpermanent structures.

\footnotetext{
20“MAGS ${ }^{\mathrm{TM}}$, an energy-generation appliance fueled by waste," Terragon Environmental Technologies, Inc., https://terragon.net/resource-recovery-solutions/energy-from-waste/.

21"Food Waste Composting at Yosemite National Park," Waste360, https://www.waste360.com/food-waste/foodwaste-composting-yosemite-national-park.
} 


\subsection{Water Reduction}

\subsubsection{Vehicle Washing and Dust Abatement}

Vehicle washing and dust abatement activities consume large quantities of potable water (see Figure 13).

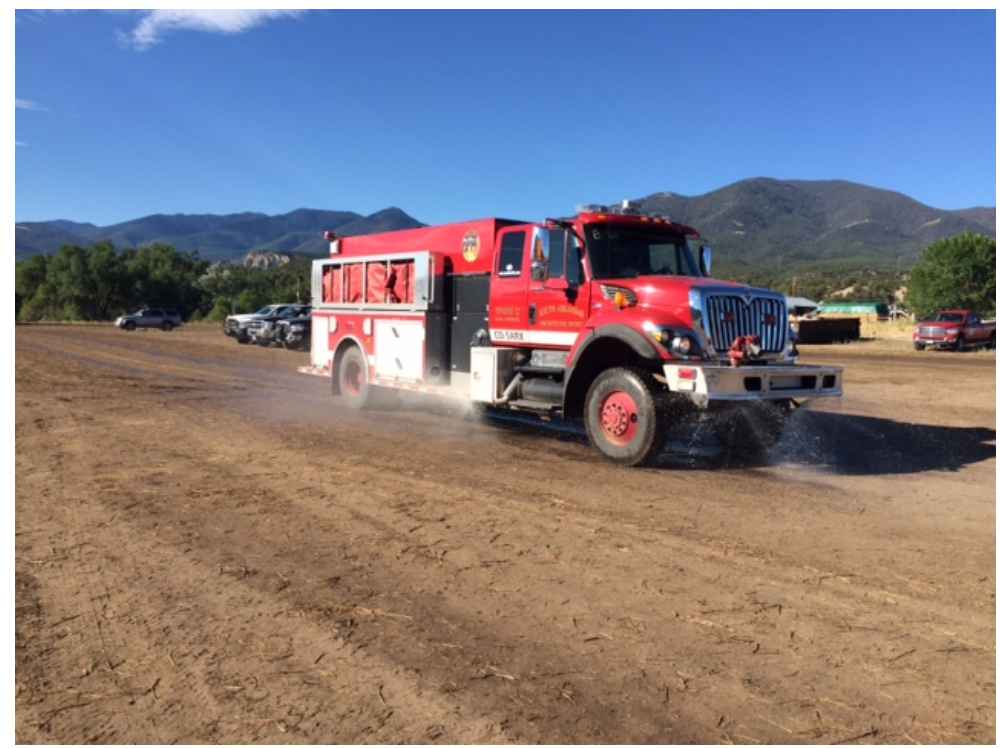

Figure 13. Dust abatement activities at the Hayden Pass Fire

Photo by Alicen Kandt, NREL

In some communities, opportunities may exist to use nonpotable, recycled water for these purposes. Also, noxious weeds vary from location to location, and vehicle washing to avoid spreading to other sites may not be necessary at every incident. Consider revisiting requirements and opportunities associated with vehicle washing and dust abatement to identify opportunities for water savings or alternative water use.

Next steps and additional considerations: Examine the potential to have the Sustainable Operations Coordinator research noxious weeds in the area of each incident and determine whether vehicle washing is necessary, and to what degree and frequency. Also consider the potential to have the SusOps Coordinator research the availability of recycled or grey water in the vicinity of the ICP and base camp operations. Consider a pilot to test these responsibilities for the SusOps Coordinator and to identify the availability of related information and the time burden for such research on the Coordinator, versus the benefit of reduced water use and associated water cost savings.

\subsection{Waste Management and Reduction}

The USFS has been proactively working to minimize its waste generation and increase its recycling and composting efforts associated with fire operations. In this vein, the USFS has undertaken waste-stream analyses to quantify its waste generation, has required composting by its caterers, and supports recycling efforts. 


\subsubsection{Composting}

Current practices and contracting requirements ensure that catering contractors provide compostable utensils, plates, and cups, and collect these items and associated food waste in compostable bags. Although this is an effective first step in implementing composting in fire camp operations, this waste is seldom composted. No requirement or oversight ensures that the catering contractor disposes of the compostable waste in a composting facility. Often, no such facility is in the vicinity of the fire, and the compostable waste is disposed of in the trash. This results in a lost opportunity to maximize the return on investment in compostable products.

Also, compostable water bottles are commercially available, which could serve as another potential waste-reduction opportunity. However, they are only beneficial if they are composted in a composting facility. If they are recycled or thrown away, the benefit associated with the bottle being compostable is not realized.

Next steps and additional considerations: Investigate the feasibility of requiring (via contracting language) the catering contractor to dispose of all compostable waste in a composting facility. In lieu of this option, the SusOps Coordinator could identify the proximity of composting facilities to the incident and communicate this information to the catering contractors. Or, if a third party is managing the recycling for the incident, they could also be tasked with the eventual disposal/hauling off-site of the compostables. A pilot could be conducted with compostable water bottles, in an incident where they will be able to be composted, and users could be surveyed to gather feedback on the bottles and the disposal process.

\subsubsection{Multiple Meal-Size Options}

Food waste is a common issue at the fire camps. Crews are given 6,000 calories per day, and although many of the support staff do not need or consume 6,000 calories per day, caterers are required to serve the full 6,000 calories per day to every person, despite dietary preferences or restrictions such as allergies. This results in a large amount of uneaten food waste. The USFS could revisit the caloric requirement to determine whether 6,000 calories is an appropriate amount for crew members. The USFS could also examine the potential to have two meal sizesa crew meal (larger, full-caloric requirements) and a staff meal (smaller, fewer calories).

Uneaten food is disposed of differently from one incident to the next; it is sometimes thrown out, donated to a local shelter, or given to livestock in areas where landowners have evacuated and are not able to feed their animals. Creating uniform guidance for disposing of food waste, and identifying IMT staff to support these efforts, will lead to waste minimization.

Next steps and additional considerations: Revisit the caloric requirement for crews. Speak with catering contractors to discuss the feasibility, cost, and time implications of creating two meal sizes. Consider conducting a cost-benefit analysis to examine the costs associated with preparing two meal sizes versus the savings associated with less food waste. Consider adding the responsibility of identifying an off-taker for food waste to the job requirements associated with the SusOps Coordinator. 


\subsubsection{Recycling}

Recycling is not widespread across all incident operations. Barriers include cost, lack of ownership and time to research recycling options in the local community and procure those services, lack of communication to crews and support staff regarding what materials can be recycled and where, and lack of directive requiring or encouraging widespread adoption of recycling practices. Creating recycling goals or requirements, and identifying staff to be responsible for all related logistics, will reduce waste and potentially reduce costs associated with waste removal. Hiring a contractor to handle recycling is one strategy that could be deployed to increase recycling rates without adding the burden of overseeing recycling logistics to an IMT staff member.

Next steps and additional considerations: Investigate appropriate IMT position to be responsible for recycling logistics. Consider adding this responsibility to the job requirements for the SusOps Coordinator. The SusOps Coordinator could also be tasked with procuring (or developing if not available) a map of available recycling and composting facilities throughout the United States. Alternatively, investigate the potential to hire a vendor to handle recycling. Staff from the IMT that supported the Whitewater Fire could be reached for information, feedback, and lessons learned from their experiences with hiring and using a vendor to handle recycling. Also, consider conducting a cost-benefit analysis of recycling versus no recycling, including the costs to transport both recyclables and waste, versus waste only.

\subsubsection{Electrolyte Powder}

Many crew members drink electrolyte (sports) drinks to help with hydration, as seen in Figure 14. The plastic waste associated with these drinks is very large in quantity, and the issue is exacerbated at incidents where recycling is not available. Electrolyte powder can be added to water in a personal-use container or in a cubie, thus eliminating associated plastic-bottle waste.

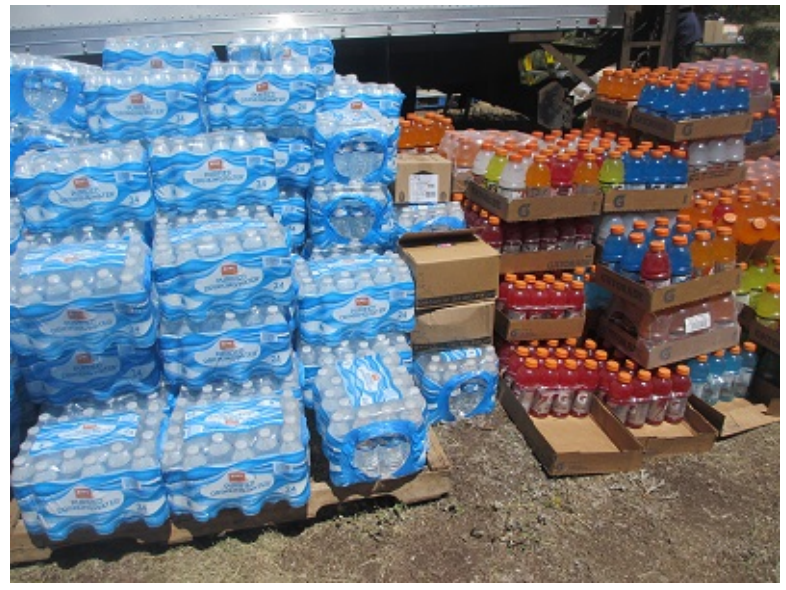

Figure 14. Water and sport drink bottles for crews at the Cold Springs Fire base camp Photo by Alicen Kandt, NREL

Next steps and additional considerations: Consider implementing a formal pilot at one or two incidents, and survey crews to get feedback regarding taste, effectiveness, and ease of use of electrolyte powder in lieu of bottled sports beverages. Consider conducting a cost-benefit analysis of bottled sports beverages versus electrolyte powder, including waste generation and waste or recycling removal costs. 


\subsubsection{Rechargeable Batteries in Radios}

The use of radios with rechargeable lithium-ion batteries has the potential to drastically reduce battery waste. This technology is already being deployed effectively in Alaska and should be considered for much broader deployment in incident operations. More information on the use of rechargeable batteries in handheld devices can be found in the USFS National Technology and Development Program publication "Hand-held Devices: Recharging Batteries in the Field." 22

Next steps and additional considerations: Building on findings and outcomes from the USFS National Technology and Development Program study, ${ }^{23}$ implement a formal pilot at one or two incidents and survey crews to get feedback regarding functionality of rechargeable batteries (including time to charge, life of charge, and life of battery), ease of recharging batteries during an incident, and ease of packing out batteries for charging. In addition to or in lieu of a pilot, IMT staff who have supported Alaska incidents could be contacted for information, feedback, and lessons learned from their experiences using rechargeable batteries in radios. Consider conducting a cost-benefit analysis of rechargeable batteries versus standard, nonrechargeable batteries, including waste generation and waste or recycling removal costs.

\footnotetext{
${ }^{22}$ Ted Etter and David J. Plummer, Hand-held Devices: Recharging Batteries in the Field (Missoula, MT: U.S. Department of Agriculture, Forest Service, National Technology and Development Program, 2011), https://www.fs.fed.us/t-d/php/library_card.php?p_num $=1166 \% 202314$.

${ }^{23}$ Ibid.
} 


\section{Conclusion}

The fire camp visits and assessments conducted in 2016 and 2017 by NREL and USFS staff were initial activities to understand fire camp operations and associated energy and water use and waste generation. An abundance of potential opportunities, next steps, and considerations have been identified, as well as some challenges and constraints.

In collaboration with USFS staff, NREL researchers hope to vet the ideas proposed in this document and gather additional ideas not yet considered from GFT members to include in future iterations of this document. NREL staff anticipate that USFS staff will select one or multiple ideas to pilot during the 2019 fire season. NREL will be available to conduct additional fire camp visits and support the piloting of selected best management suggestions, as needed. The intent is that after suggestions are further investigated, and in some instances piloted, a Best Management Practices guide for SusOps in fire camps can be developed, published, and broadly disseminated to the fire community. It is likely that this will take several more years to develop and finalize.

Fire camp operations are complex, multiagency efforts driven by a singular mission. Sustainable operations have an inherent role in fire camps and can help reduce the costs of fighting fires and thus free up additional funds to support the mission. 


\section{Glossary}

\begin{tabular}{|c|c|}
\hline Term & Definition \\
\hline Base camp & $\begin{array}{l}\text { The location where primary logistics functions for an incident are coordinated and administered. } \\
\text { There is only one base per incident. (Incident name or other designator will be added to the term } \\
\text { "base.") The Incident Command Post may be co-located with the base. }\end{array}$ \\
\hline Cache & $\begin{array}{l}\text { Supply of fire tools and equipment assembled in planned quantities or standard units at a strategic } \\
\text { point for exclusive use in fire suppression. }\end{array}$ \\
\hline Cubie & $\begin{array}{l}\text { Portable container, made from cardboard and plastic, capable of holding } 5 \text { gallons of water. } \\
\text { Typically available from supply cache. }\end{array}$ \\
\hline $\begin{array}{l}\text { Extended } \\
\text { attack } \\
\text { incident }\end{array}$ & $\begin{array}{l}\text { A wildland fire that has not been contained or controlled by initial attack forces and for which } \\
\text { more firefighting resources are arriving, en route, or being ordered by the initial attack incident } \\
\text { commander. }\end{array}$ \\
\hline Fire box & Container specifically designated to store incident documents for the long term. \\
\hline Fire camp & $\begin{array}{l}\text { Geographical site(s) within the general incident area separate from the incident base, equipped and } \\
\text { staffed to provide sleeping, food, water, and sanitary services to incident personnel. }\end{array}$ \\
\hline Fire line & A linear fire barrier that is scraped or dug to mineral soil. \\
\hline Fire season & $\begin{array}{l}\text { Period(s) of the year during which wildland fires are likely to occur, spread, and affect resource } \\
\text { values sufficient to warrant organized fire management activities. }\end{array}$ \\
\hline $\begin{array}{l}\text { Greening Fire } \\
\text { Team (GFT) }\end{array}$ & $\begin{array}{l}\text { Established in } 2009 \text { under the Sustainable Operations organization, the GFT is tasked with } \\
\text { reducing the ecological footprint at fire camps by developing best management practices and } \\
\text { supporting the integration of them into the fire community. }\end{array}$ \\
\hline Hotshot crew & Intensively trained fire crew used primarily in handline construction (Type-1) \\
\hline $\begin{array}{l}\text { Incident } \\
\text { Command } \\
\text { Post (ICP) }\end{array}$ & $\begin{array}{l}\text { Location where primary command functions are executed. The ICP may be co-located with the } \\
\text { incident base or other incident facilities. }\end{array}$ \\
\hline $\begin{array}{l}\text { Incident } \\
\text { Management } \\
\text { Team (IMT) }\end{array}$ & $\begin{array}{l}\text { The incident commander and appropriate general and command staff personnel assigned to an } \\
\text { incident. }\end{array}$ \\
\hline $\begin{array}{l}\text { Net zero } \\
\text { waste } \\
24\end{array}$ & $\begin{array}{l}\text { A net zero waste facility reduces and reuses waste and converts it to something valuable (such as } \\
\text { compost or energy) to a point where nothing is sent to the landfill. }\end{array}$ \\
\hline $\begin{array}{l}\text { Net zero } \\
\text { water }{ }^{25}\end{array}$ & $\begin{array}{l}\text { A net zero water facility limits the consumption of freshwater resources and returns water back to } \\
\text { the same watershed, not depleting the groundwater and surface water resources of that region in } \\
\text { quantity or quality over the course of a year. }\end{array}$ \\
\hline Reefer truck & $\begin{array}{l}\text { A refrigerated truck, located at base camp where firefighters to go to get lunches, ice, bottled } \\
\text { water, etc. }\end{array}$ \\
\hline Region $10^{26}$ & USFS region covering Alaska \\
\hline Region $6^{27}$ & USFS region covering the Pacific Northwest (Oregon and Washington) \\
\hline Spike camp & $\begin{array}{l}\text { A smaller, remote camp, usually near a fire line, lacking the necessities that the base camp would } \\
\text { provide. }\end{array}$ \\
\hline SusOps & $\begin{array}{l}\text { USFS Sustainable Operations organizational team focused on helping the USFS reduce the } \\
\text { environmental footprint of FS operations and promoting being a leading example of a green } \\
\text { organization. }\end{array}$ \\
\hline
\end{tabular}

${ }^{24} \mathrm{https://www.ff.fed.us/sites/default/files/factsheets-netzero.pdf}$

${ }^{25} \mathrm{https://www.fs.fed.us/sites/default/files/factsheets-netzero.pdf}$

${ }^{26} \mathrm{https://www.fs.usda.gov/main/r10/home}$

${ }^{27}$ https://www.fs.usda.gov/r6 


\begin{tabular}{|l|l|}
$\begin{array}{l}\text { SusOps } \\
\text { Coordinator }\end{array}$ & $\begin{array}{l}\text { A technical specialist assigned to incidents to assist the IMT with implementing sustainable best } \\
\text { management practices. }\end{array}$ \\
\hline Type 1 Fire 28 & $\begin{array}{l}\text { Refers to resource capability and complexity of an extended-attack incident. Personnel often } \\
\text { exceed 1,000. Involves several types of aircraft and is often greater than 5,000 acres in size. }\end{array}$ \\
\hline Type 2 Fire ${ }^{29}$ & $\begin{array}{l}\text { Refers to resource capability and complexity of an extended-attack incident. Personnel often } \\
\text { exceed 500. Involves several types of aircraft and is often greater than 1,000 acres in size. }\end{array}$ \\
\hline Type 3 Fire $^{30}$ & $\begin{array}{l}\text { Refers to resource capability and complexity of an extended-attack incident. Typically smaller in } \\
\text { the number of personnel, incident size, and duration. }\end{array}$ \\
\hline
\end{tabular}

28

https://www.nifc.gov/nicc/logistics/references/Wildland\%20Fire\%20Incident\%20Management\%20Field\%20Guide. pdf, page 28

29

https://www.nifc.gov/nicc/logistics/references/Wildland\%20Fire\%20Incident\%20Management\%20Field\%20Guide. pdf, page 28

https://www.nifc.gov/nicc/logistics/references/Wildland\%20Fire\%20Incident\%20Management\%20Field\%20Guide. pdf, page 23 


\section{Appendix A. Energy Audit Questionnaire}

\section{ENERGY AUDIT QUESTIONNAIRE}

PURPOSE: This summer the Forest Service, in conjunction with National Renewable Energy Laboratory (NREL), will be conducting energy audits at selected incidents across the country. They will be monitoring the amount of electricity, fuel, and water being consumed, and analyze the waste stream that is generated. Because of your expertise in the management of logistics and/or facilities at incidents, you have been selected to provide input to NREL so that they may establish a baseline for their analysis.

DIRECTIONS: Please take a few minutes and answer the questions to the best of your ability and provide any comments. Try to think of consumption/cost in terms of per day, if needed. It is OK to not have an exact answer.

Data needed in support of this effort (on a camp basis (camp by camp)):

I. Description of Incident: Location (State/Forest or District)

Type $(1,2,3)$ :

Number of people:

Dates and duration of incident:

A. If off-grid:

- Generator specifications (make, model, capacity, fuel type):

- Fuel use:

- Fuel cost:

- Dates used at fire camp (if different than operation of fire camp):

A. If on-grid:

- kWh use:

- kWh cost:

- Dates grid-tie was used at fire camp (if different than operation of fire camp):

B. Water use:

C. Water cost:

D. Waste generated:

E. Recycling generated:

II. General comments or observations: 


\section{Appendix B. Greening Fire Tips}

\section{Greening Fire IIP}

\section{Consider Bulk Water on Fires}

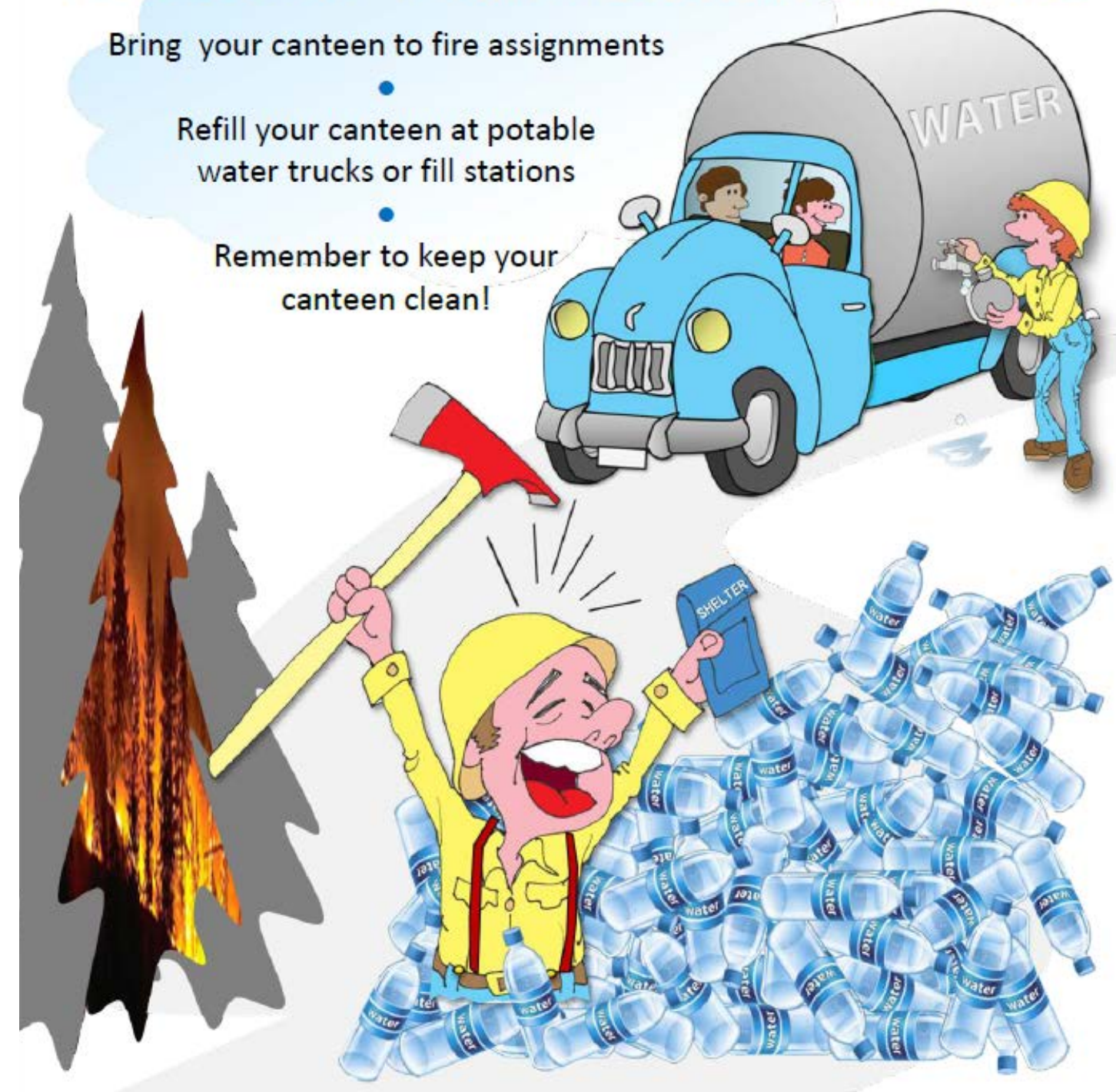

Don't drown in refuse, just hydrate through reuse! 


\section{Appendix C. Building Energy Modeling}

The data collected during the fire camp audits were used to create eQUEST31 building energy models of the three different structure types most commonly used in fire camps, including the following:

- Tent: $580 \mathrm{ft}^{2}$

- Mobile office trailer: $320 \mathrm{ft}^{2}$

- Hard structure assumed to be a school: $16,875 \mathrm{ft}^{2}$

Building energy modeling is essential to understanding what the current energy consumption is, where the highest consumers are (e.g., HVAC, lights, fans, pumping, etc.), and calculating potential energy savings associated with identified energy efficiency opportunities. This section outlines the building energy models that NREL created. Each of the energy models used Flagstaff, Arizona, hourly weather data, and the models were only simulated for the month of August (as opposed to the entire year), because forest fires are most common during the summer months. Flagstaff was the location of the Boundary Fire audited by the USFS/NREL team on June 19, 2017.

The NREL team modeled existing operating conditions of HVAC, lighting, and plug-load systems. A representative photo of the building type and a graphical representation of the building energy models developed in eQUEST are shown below for each building type. Note that the representative photo used for the hard structure is from a ski lodge from the Whitewater Fire near Bend, Oregon, and the energy model developed was assumed to be a hypothetical school, because this is the most common hard structure used in fire camps. The geometry of the buildings was simplified for modeling purposes while still allowing accurate simulations of energy transfer through all building surfaces.

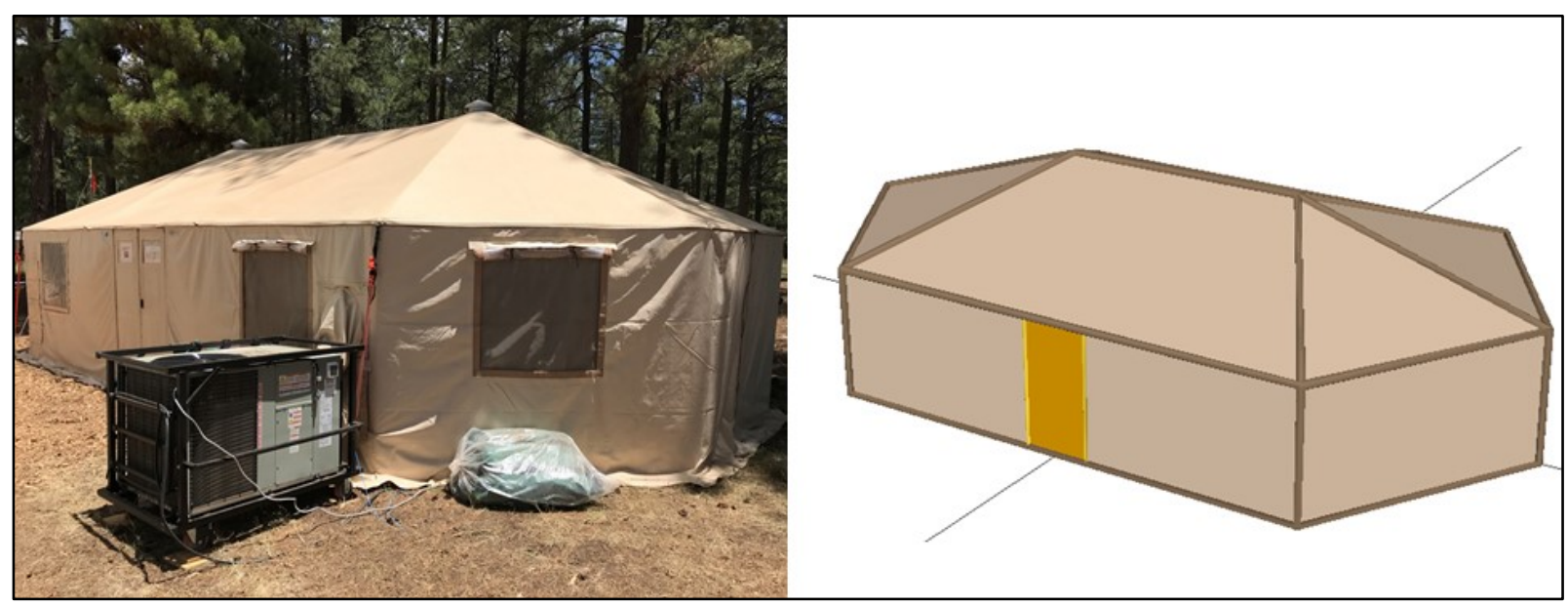

Figure 15. Representative tent photo and eQUEST model representation

\footnotetext{
${ }^{31}$ To learn more about eQuest, visit http://www.doe2.com/equest/.
} 


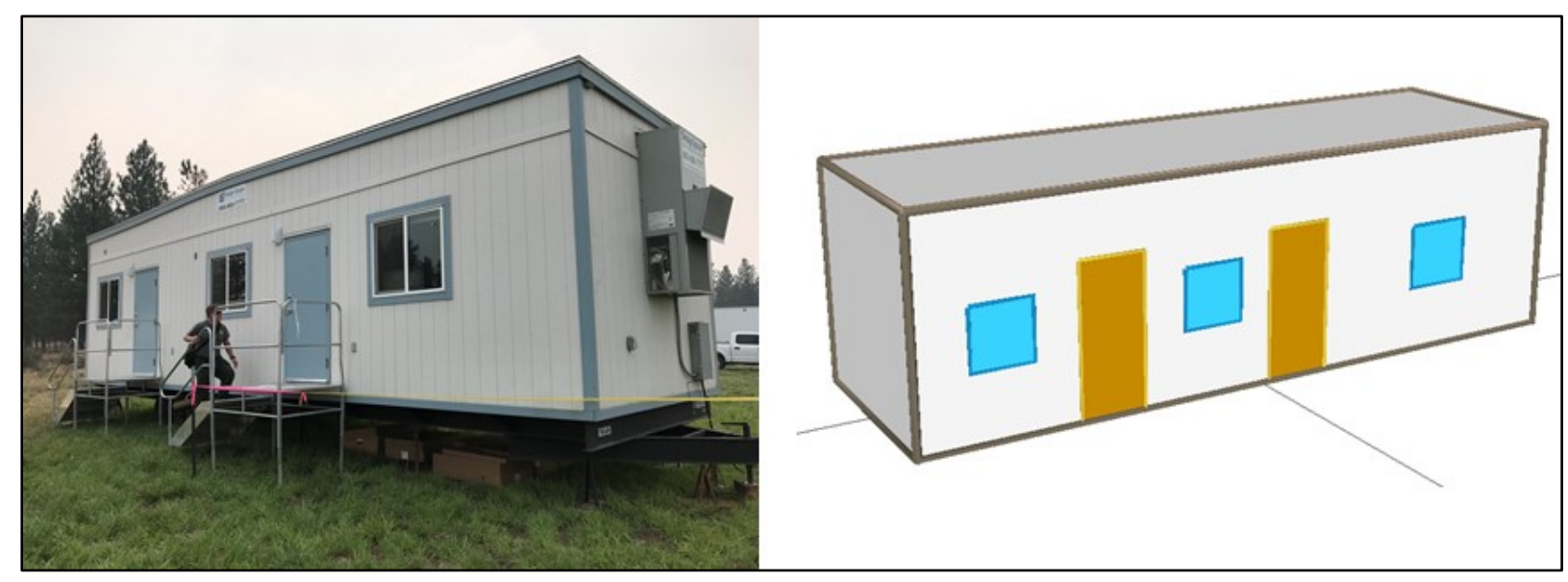

Figure 16. Representative mobile office trailer photo and eQUEST model representation

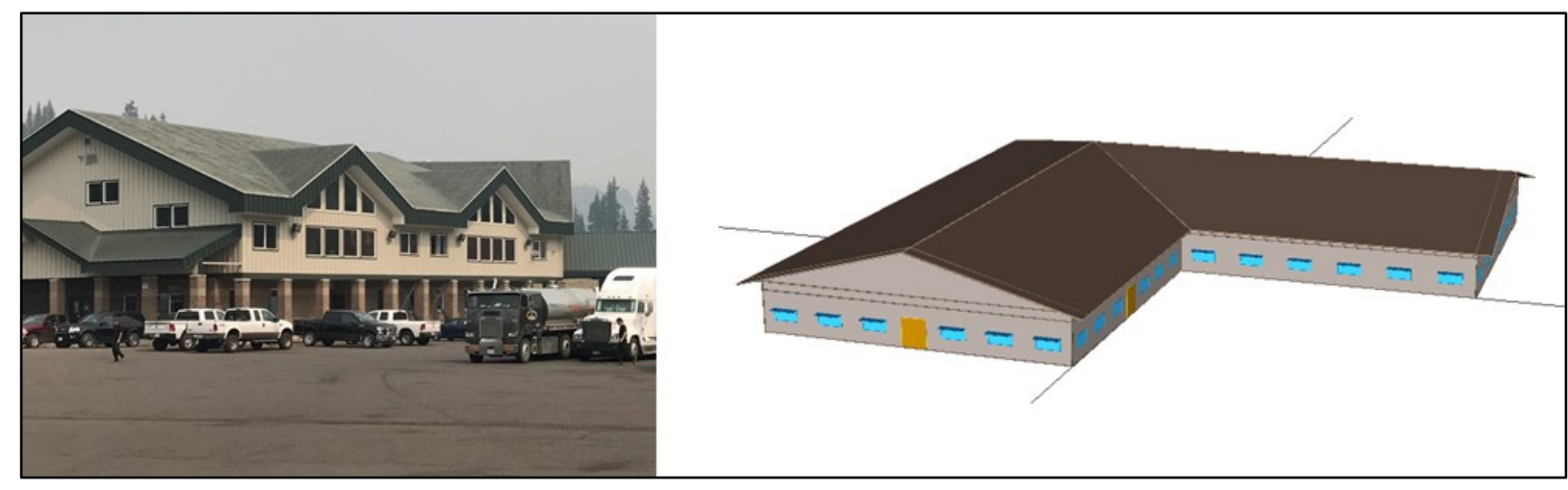

Figure 17. Representative hard structure photo and eQUEST model representation

Estimates of the current energy-use breakdown for the various building types typically found at fire camps were generated using the eQUEST building energy model and are presented in the graphs below. As shown, the common loads include space cooling in blue, lighting in yellow, plug-load equipment (e.g., computers, printers, monitors) in green, and HVAC fans in pink. 

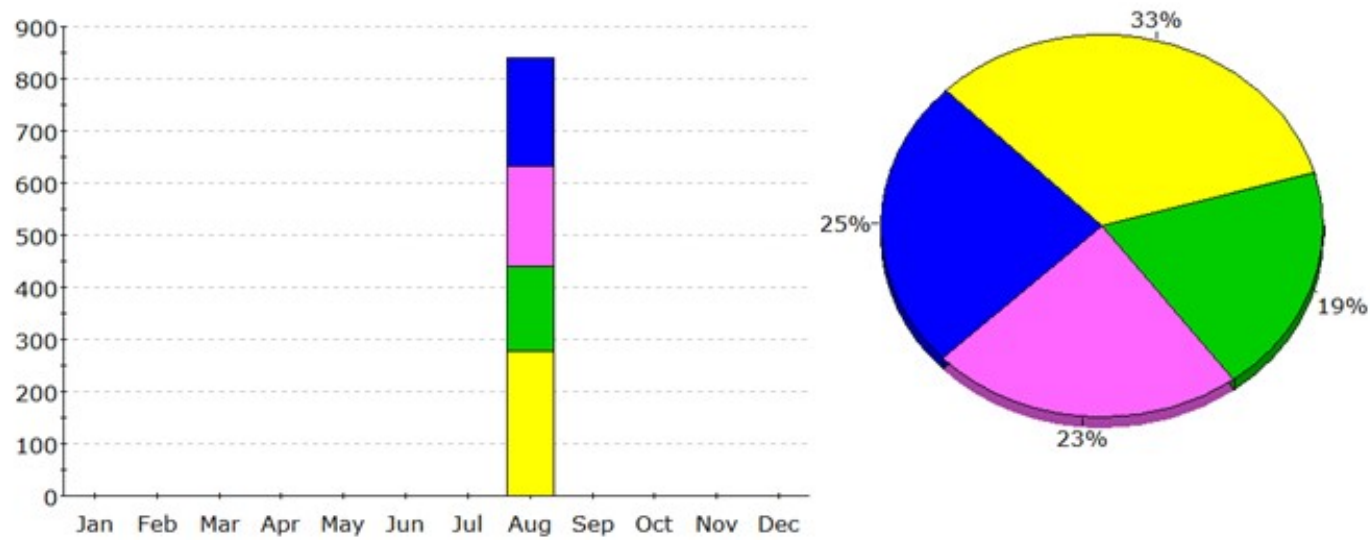

Jan Feb Mar Apr May Jun Jul Aug Sep Oct Nov Dec

Area Lighting

Task Lighting

Misc. Equipment

Exterior Usage
Pumps \& Aux.
Ventilation Fans

Water Heating Ht Pump Supp.

Space Heating

Refrigeration

Heat Rejection

Space Cooling

Figure 18. Tent baseline energy use estimates

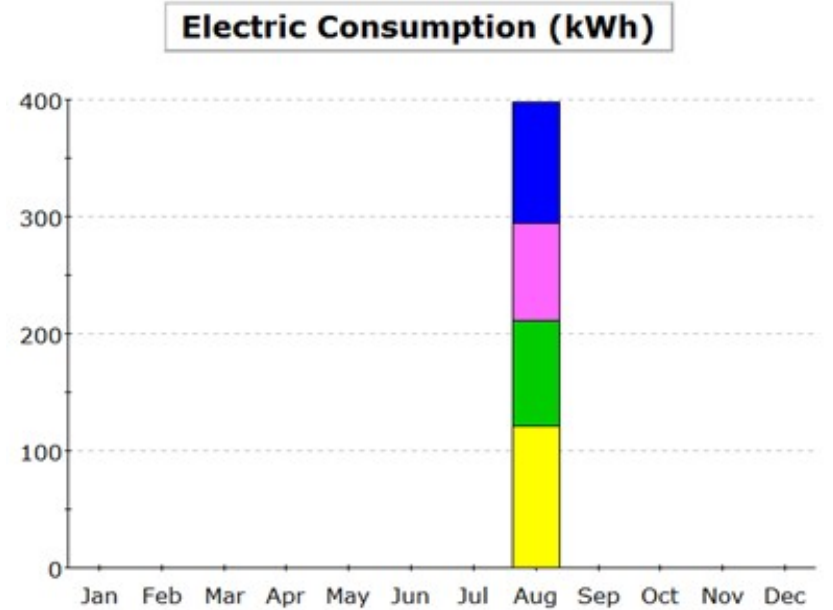

\section{$1.24 \mathrm{kWh} / \mathrm{ft}^{2} /$ month}

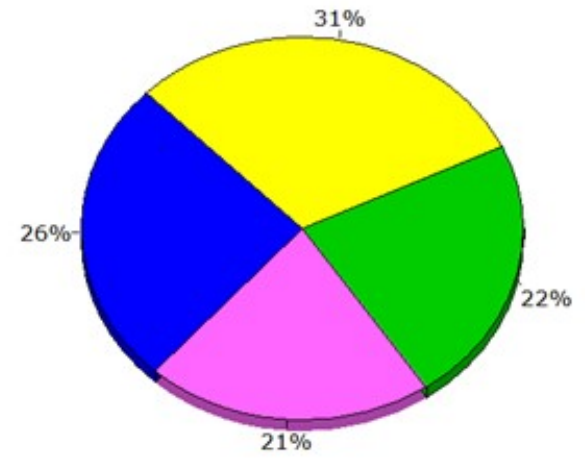

Area Lighting

Task Lighting

Exterior Usage

Pumps \& Aux.

Ventilation Fans

$\square$

Water Heating

Ht Pump Supp.

Space Heating

Refrigeration

Heat Rejection

Space Cooling

Figure 19. Mobile office trailer baseline energy use estimates 


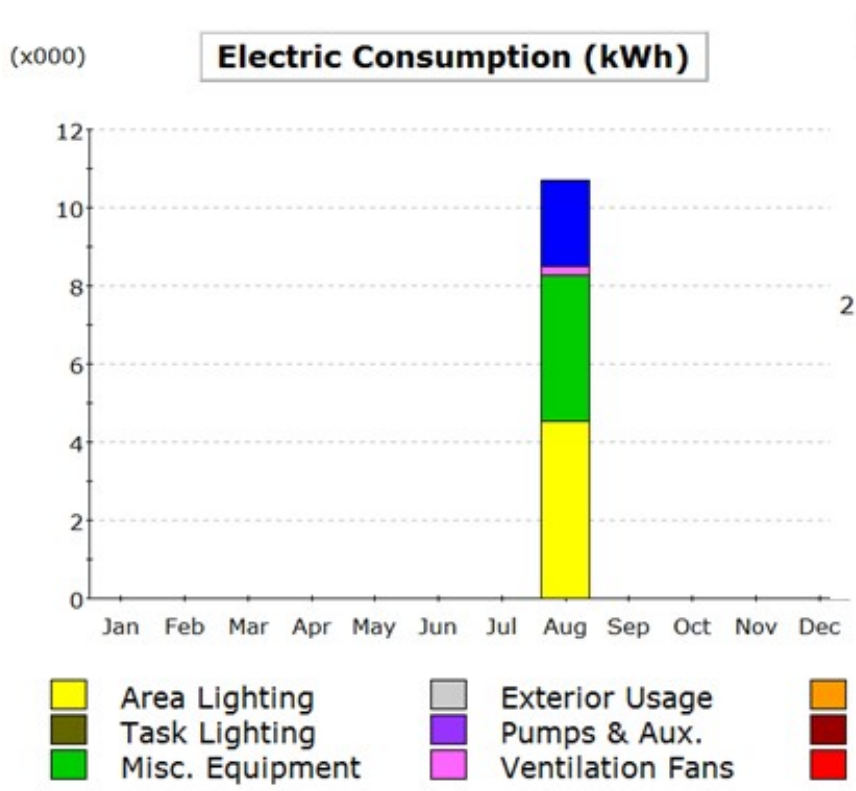

\section{$0.64 \mathrm{kWh} / \mathrm{ft}^{2} /$ month}

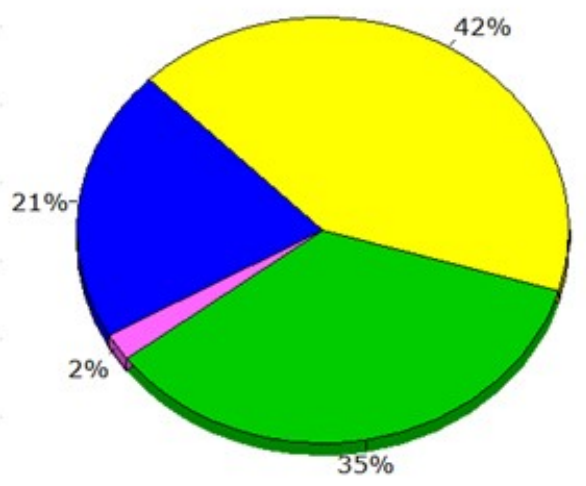

Figure 20. Hard structure school baseline energy use estimates

\section{C.1 Modeling Results}

NREL conducted an analysis using the energy models to compare the energy-use intensity (EUI) of each building type. This is the most straightforward way to compare the energy efficiency of various building types given that the building areas are different. The EUI is typically the annual energy use divided by the area of the building, which normalizes the energy use over various building sizes. Because the energy models were only simulated for the month of August, the EUIs present below are monthly and have the units of $\mathrm{kWh} / \mathrm{ft}^{2} /$ month. The lower the EUI, the lower the energy use of the building. As shown in the figure below, tents have the highest EUI, followed by mobile office trailers, and then, hard structures. This indicates that when hard structures are available, they have the lowest EUI and provide the added benefits of eliminating dust issues and having grid power, and should be prioritized for incident operations. 


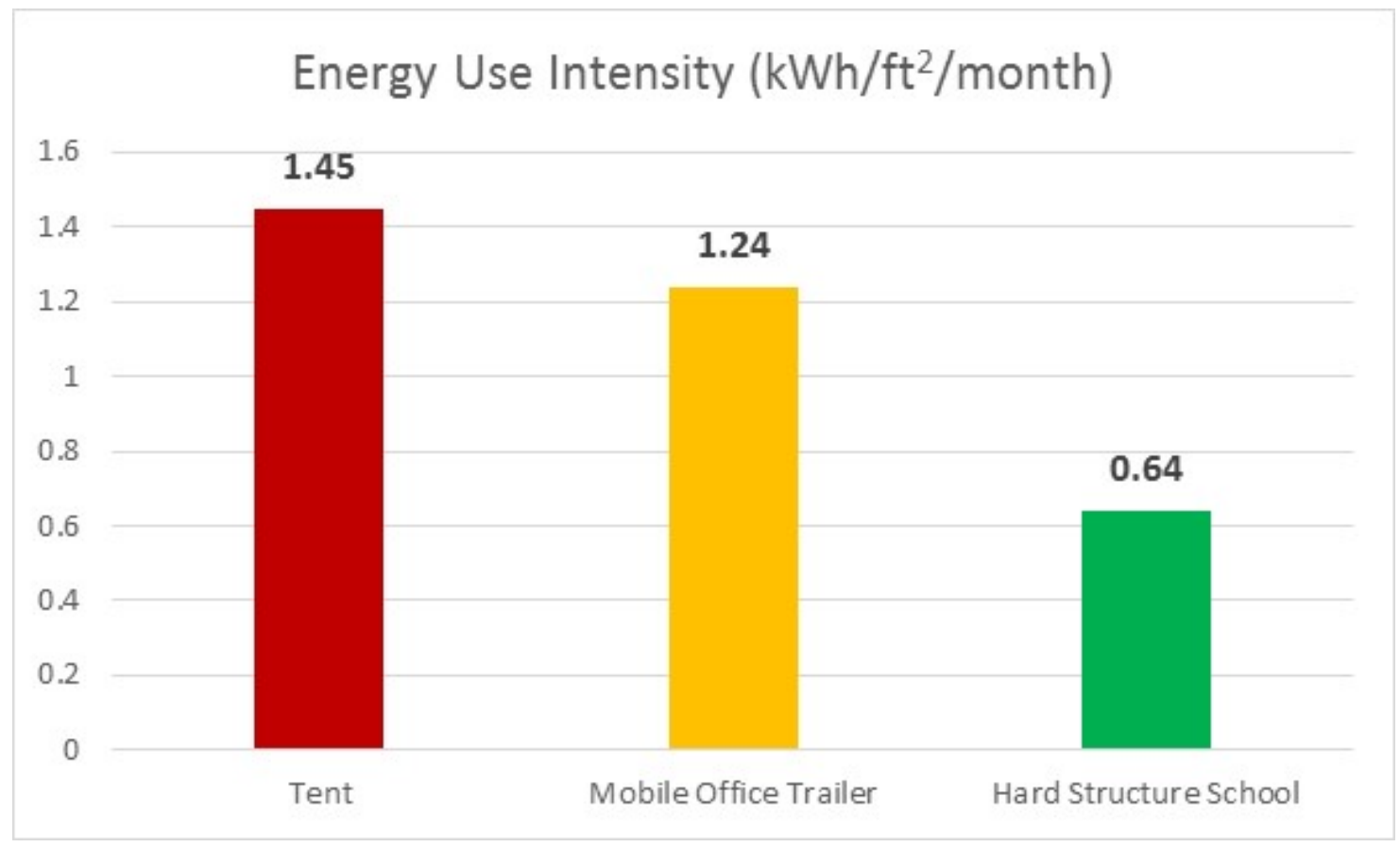

Figure 21. Energy use intensity comparison 